Using the Material and Written Sources: Turn of the Millennium Approaches to Roman Domestic Space

Author(s): Penelope M. Allison

Source: American Journal of Archaeology, Vol. 105, No. 2 (Apr., 2001), pp. 181-208

Published by: Archaeological Institute of America

Stable URL: http://www.jstor.org/stable/507270

Accessed: 11/12/2013 10:55

Your use of the JSTOR archive indicates your acceptance of the Terms \& Conditions of Use, available at http://www.jstor.org/page/info/about/policies/terms.jsp

JSTOR is a not-for-profit service that helps scholars, researchers, and students discover, use, and build upon a wide range of content in a trusted digital archive. We use information technology and tools to increase productivity and facilitate new forms of scholarship. For more information about JSTOR, please contact support@jstor.org. 


\title{
Using the Material and Written Sources: Turn of the Millennium Approaches to Roman Domestic Space
}

\author{
PENELOPE M. ALLISON
}

\begin{abstract}
The study of Roman domestic space, which has greatly expanded in the last years of this millennium, is an area of research into the classical world where both material and written sources provide important evidence. This paper outlines the types of evidence and examines several recent studies for a critical perspective on current methodological and theoretical approaches to Roman material culture. While this study demonstrates that more rigorous research is needed, it also highlights that this burgeoning interest has made substantial contributions to research on Roman domestic behavior.*
\end{abstract}

In a recent conversation with a Roman historian, I was told that history will always be more interesting than archaeology because it concerns individuals. But I am not convinced. In the first place this is not true for me. In the second place, when new students or the public are asked why they are interested in ancient history it is as often, in my experience, because the material remains have fascinated them, as that some past individual like C. Julius Caesar existed. The apparent tacticity of the Roman world provides the inspiration for many individuals to study ancient history, which they view as a means of gaining greater understanding of the society that produced these material remains. Some students become more interested in named individuals from the past, both famous and lesser figures. Others persist with their interest in the physical remains despite the overwhelming emphasis on written evidence in Western education systems. More recently, some scholars waver between these two fundamentally entwined but methodologically distinct disciplines. Rarely today does an individual scholar develop a profound and critical knowledge of appropriate approaches for both the material and the written sources. ${ }^{1}$

I also disagree with my Roman historian colleague that archaeology is not about individuals. In Roman

\footnotetext{
"I am indebted, as always, to the Soprintendenza archeologica di Pompei for permission to carry out the research at Pompeii that has provided much of the background to the views expressed in this paper. Thanks are also due to David Mattingly for the impetus with which his original suggestion some years ago provided me to write this paper. I am grateful to Lisa Ne-
}

archaeology it is generally more difficult than in the archaeology of more recent historical periods to name individuals whose activities are imprinted in the material record, but that does not mean that their activities cannot be explored. Archaeology is concerned precisely with the activities of often unnamed and unclassified individuals. Archaeologists and ancient historians should ensure that the politics of history do not overwhelm any tangible actuality of these individual lives and its importance in our investigations of human behavior in the past.

The perspective expressed by my historian colleague is entrenched in the study of the classical world generally. That is, it suffers the well-known "archaeology as the handmaiden of history" model: texts provide the key to understanding past worlds, and analyses of the material remains are not capable of presenting independent information of past lives. One of the principal reasons for this perspective is that questions are often asked of the material remains that are more applicable to the documentary sources. There is a need for rigorous and thorough material cultural approaches to the material evidence of the classical world that ask answerable questions of the material remains. The results should be tested against the ancient written evidence for consistencies and inconsistencies, rather than using literary references to "set the context."' Approaches to material cultural assemblages and contexts need to question the roots of any variability between the interpretations of the diverse sets of data and to be critically self-conscious of the inferences that result from one body of data being used to interpret another.

One of the main reasons that the investigation of material remains from the classical world has lacked rigor is that European education systems have traditionally viewed the study of "The Greats" as intel-

vett, Tim Gregory, and Aedeen Cremin for reading versions of this paper and for their comments, and to the two anonymous readers. I hope I have done justice to their comments but take full responsibility for all misunderstandings and errors.

${ }^{1}$ Dunbabin 1995, 387.

${ }^{2}$ Foss 1997, 197. 
lectually supreme and the study of the physical remains as some curious pastime, providing color but adding little intellectual depth. Snodgrass noted that there is a "longstanding and robust tradition of excavation and fieldwork" in classical archaeology but that this work has been carried out with an "assumption of the primacy of the ancient sources": the "choice of site is driven by the historical record." This disciplinary history continues to affect both the reasons for the excavation of archaeological sites in the Roman world and the interpretations of these remains. In recent decades archaeologists, including scholars working on the classical world, ${ }^{4}$ have been developing and refining their techniques and theoretical approaches to material culture. Many classical scholars continue to believe, however, that ancient written sources provide the primary window through which to view Europe's early historical past, far better than any image that can be achieved through exploration of its material remains. ${ }^{5}$ Equally, other branches of historical archaeology have only recently viewed the objectives and methodology of Roman archaeology as relevant to the broader historical archaeology discourse. ${ }^{6}$

Essentially our information on the Roman world stems from three principal sources: selected writings of contemporary authors, copied down in the Middle Ages and now presented as primary data; the physical remains, both above-ground structures and excavated material; and epigraphy, including inscribed stone monuments, painted graffiti, and papyri. With the exception of some epigraphers, few investigators of ancient written sources examine primary data. Similarly, the investigators of the material remains often rely on the rich descriptions of excavation reports or illustrated descriptions of aboveground architectural and sculptural remains as their resources. Much political history may be understood through written remains alone. Given the contexts in which many textual sources were created, however, this is not necessarily a satisfactory approach to many aspects of Roman social history.

These considerations are particularly relevant to the investigation of concepts of space in the Ro-

\footnotetext{
3 Snodgrass 1991, 58-61.

${ }^{4}$ E.g., Morris 1994; Mattingly 1997; Woolf 1998; Shanks 1999.

${ }^{5}$ See Dyson 1993, 1995, esp. 27.

${ }^{6}$ E.g., Hingley 1998; see also Storey 1999.

${ }^{7}$ Space is also being paid more attention recently by scholars whose main source of evidence is textual: e.g., Purcell 1994; Muecke 1996; Wiseman 1998.

${ }^{8}$ E.g., Clarke 1991; Moormann 1993; Wallace-Hadrill 1994;
}

man world: landscapes, urbanism, and domestic space. ${ }^{7}$ This paper focuses on the study of domestic space, a topic that has received much interest recently. ${ }^{8}$ It is a significant area in which ancient texts and material and epigraphical remains all play an active role. ${ }^{9}$ The manner in which these varying types of evidence have been studied and assimilated, however, often shows limited comprehension of the analytical approaches that have been developed for each, of the diversity of their range, and of their interrelationships.

This paper analyzes some recent studies of Roman domestic space and demonstrates how the evidence is compromised by the use of unrelated textual data to interpret material remains or by the incorporation of unsubstantiated analyses by past scholars in current interpretations. It draws particularly on material from southern Italy and the town of Pompeii, on which many recent studies of Roman domestic space have concentrated. Pompeii is often considered to be the materialization of Roman daily life and has a long history of research. If more critical approaches to relationships between documentary and material sources are needed for Campania, then this need is likely to be even more pressing for distant parts of the Roman world.

\section{STUDIES OF ROMAN DOMESTIC SPACE}

What are the objectives of a study of Roman domestic space? Generally, scholars hope to deepen their insight into human behavior during the Roman period as it takes place both in the construction and habitation of domestic settings. As a fundamental center of social behavior, the domestic setting, or household, is an ideal place from which to commence an analysis of social behavior in the Roman world more broadly. ${ }^{10}$ Scholars are concerned with the interaction between spatial settings and domestic practices as a basis for understanding more about human behavior and interrelationships in the past. They are attempting to do this through developing an understanding of the relationships of people in the past in their "everyday" lives; the functions and meanings of the spatial set-

Anderson 1997; Bon and Jones 1997; Laurence and WallaceHadrill 1997; Pesando 1997; Rawson and Weaver 1997; Smith 1997. As Dunbabin $(1995,387)$ noted, this trend commenced in the 1980s, but with concerns for domestic architecture as part of urban space and with comparatively little investigation of Campanian houses.

${ }^{9}$ See esp. Nevett 1997.

${ }^{10}$ For a comparable approach to Greek houses, see Nevett 1999. 
ting of these "everyday" lives; and the relationships between the two. Many recent studies confuse these aims and processes by using secondary sources as primary sources, by mixing one process with another, or by asking questions of one class of material that are better suited to another. For example, written sources are best suited for providing insights into the interpersonal relationships of people in the past (e.g., status, emotions, etc.) although sometimes, as discussed below, they provide information on the spatial organization of domestic spheres. The material remains are better suited to provide information on the physical actuality of those domestic spheres, particularly their diversity, and on the activites that took place within them. While individual actors may be represented in both realms in more recent historical periods, this is rarely the case in Roman history. ${ }^{11}$

In order for the investigation of Roman domestic space to progress further, a self-critical approach is needed, as is a sound understanding of the nature of the evidence and of the development of the methods used to reveal relationships between the social and the material in the past. Below, I outline the primary sources of evidence used in studies of domestic space and discuss some of the analytical procedures that are being applied to this evidence, illustrating how some analyses have included inappropriate processes and past interpretations, frequently as primary data, to produce unsubstantiated interpretations. These, in turn, produce misleading perspectives about domestic behavior in the Roman world.

\section{THE DATA}

\section{Ancient Authors}

Very little of the fragmentary remains of Roman written works pertains directly to living conditions in the Roman world; still less do they pertain to domestic practices and their physical setting. While glimpses can be gleaned from such sources as legal and talmudic ${ }^{12}$ texts and papyri, a limited number of principal ancient authors are continually drawn on to provide evidence of how Romans played out their domestic lives, because the agenda of these particular sources concerns the spatial organization of the domestic sphere.

\footnotetext{
${ }^{11}$ Cf., e.g., Karskens 1997. See also Allison 1998.

${ }^{12}$ See, e.g., Krauss 1966.

${ }^{13}$ Becker 1876, 231-80. Compare plan A with plan B in this edition.

${ }^{14}$ Ep. 2.17 .
}

The ancient author most frequently linked with studies of Roman domestic space is Vitruvius. Not only were his writings an inspiration for much Renaissance domestic architecture, but W.A. Becker's early study of the Roman house, the original edition of which preceded the extensive excavation of Roman houses (e.g., at Pompeii), drew heavily on Vitruvius's prescriptions in order to produce a house plan without the aid of physical evidence. ${ }^{13}$ The writings of Vitruvius, especially books VI and VII, provide detailed information on the ideal perspectives, dimensions, and construction methods for Roman houses. His work is fundamental to understanding how at least one Roman architect viewed the construction of the built environment in the early Empire. His detailed specifications for measurements of the various spaces within a Roman house clearly demonstrate his concerns for symmetry and proportion but also provide a key to the nomenclature of these spaces, along with their ideal spatial and dimensional interrelationships. As an architect, Vitruvius himself was not primarily concerned with domestic space as lived space; thus, his references to furnishings, behaviors, or activities within the described spaces are limited.

Other principal ancient authors whose writings provide information on the nomenclature and interrelationships of domestic spaces are Varro and Pliny the Younger. Like Vitruvius, Pliny the Younger provides little evidence of domestic behavior. His descriptions of his "Laurentinum" 14 and his property in Tuscany ${ }^{15}$ read like real estate advertisements, highlighting the settings of particular domestic apartments. His aim was to entice his reader and friend to visit him and to display his expertise in architectural terminology, ${ }^{16}$ rather than to describe the activities and interrelationships of the various family members, slaves, and others who occupied the villas.

Varro gave perhaps a more useful perspective on relationships between Latin nomenclature and household behavior. ${ }^{17} \mathrm{He}$ implied that this nomenclature was not explicit, being interchangeable and changing over time. There is notably little relationship between his etymology and the terminology used by Vitruvius or Pliny. For example, the only term they have all used is cubiculum. Vitruvius used it only twice for Roman houses ${ }^{18}$ and twice for Greek

\footnotetext{
${ }^{15} \mathrm{Ep} .5 .6$

${ }^{16}$ See Förtsch 1993; Drummer 1994.

${ }^{17}$ De ling. lat. 5.161-2.

${ }^{18}$ De arch. 6.4.1 and 6.5.1.
} 
houses, ${ }^{19}$ giving no indication of the location of a sonamed space within the house plan. Pliny used the term frequently for a variety of rooms in both his villas with no apparent locational specificity. Similarly, the many other references to this term cited by Andrew Riggsby give little evidence to its physical form or location. ${ }^{20}$ The term does not seem to have any specific functional meaning to Latin writers beyond being perhaps symbolic of privacy. ${ }^{21}$ This particular example suggests that the more a term was used in the written sources, the more diverse can be its meaning, and the more difficult and ineffectual can be any attempts to relate it to the extant physical spaces in Roman houses.

It is perhaps because of the paucity of information that these ancient authors provide on domestic behavior and interpersonal relationships that Vitruvius is cited only once in Jane Gardner and Thomas Wiedemann's sourcebook on the Roman household. ${ }^{22}$ Only two references to Varro appear in this book, neither of which cites his discussion on room nomenclature. ${ }^{23}$ Similarly, none of the 14 quotations from Pliny's letters cited in this book are taken from his descriptions of his villas. With the exception of the one citation from Vitruvius, Gardner and Wiedemann have not considered domestic space as a relevant topic in their study of textual references to Roman household behavior. As stated above, written sources can provide considerable insights into the interrelationships of people within Roman households, ${ }^{24}$ but the ancient authors in general do not provide very useful information on the spatial aspects of household behavior.

\section{Epigraphy}

Epigraphical evidence is particularly important for recent concerns of Roman social history as it often pertains to groups of people who are not well represented in the works of ancient authors. Although the written data from these inscriptions have often been fastidiously documented and studied, information on their physical characteristics and precise contexts is frequently lacking, as is demonstrated by the lack of precise contextual information in the Corpus Inscriptionum Latinarum. For this reason, scholars working with such evidence often

\footnotetext{
${ }^{19}$ De arch. 6.8.2

${ }^{20}$ Riggsby 1997.

"I See Leach 1997; Nevett 1997, 291-2; Riggsby 1997.

${ }^{22}$ Gardner and Wiedemann 1991, 9-10.

${ }^{23}$ Gardner and Wiedemann 1991, 70, 109.

${ }^{24}$ For discussions, see Gardner and Wiedemann 1991, 129. See also Bettini 1991; Bradley 1991; Dixon 1992; Rawson and Weaver 1997.
}

cannot reconstruct its material context. ${ }^{25}$ Furthermore, because much epigraphical material is either funereal or dedicatory, ${ }^{26}$ such monuments may provide information on familial interrelationships, but the household relationships of these individuals are less evident.

Thus, epigraphical remains have been more useful for investigations of the composition of households than for study of the social use of space. For example, Valerie Hope has used epitaphs, still in situ in the Isola Sacra necropolis near Ostia and at Aquileia, to demonstrate relationships between tomb and house and thus the flexibility of household membership. ${ }^{27}$ While such evidence does not directly inform on domestic space, it informs on household compositions in central Italy in the earlier Roman Empire and can lead to inferences about the complexity of relationships within these households. Such information serves to warn of the dangers of making assumptions about the separation of domestic space according to binary oppositions. ${ }^{28}$ These inscriptions give similar types of evidence about household composition as that gleaned from ancient authors rather than from material culture, but in this case with good material contexts.

\section{Material Culture}

In contrast to the scant written evidence for Roman domestic space, extensive material evidence of housing is found throughout the Roman world from Britain to Mesopotamia, from traces of possible sixth-century B.C. housing on the Palatine in Rome $^{29}$ to late fifth-century A.D. occupation at Karanis in Egypt. ${ }^{30}$ While many of these remains consist predominantly of traces of wall footings or only residues of former dwellings, ${ }^{31}$ substantial architectural remains, house contents, and wall, floor, and ceiling decoration have also been identified at numerous sites. Some of the most extensive material evidence for Roman domestic space is found at Pompeii.

The usefulness of any of this material evidence for investigations into the spatial relationships of domestic behavior is dependent not only on its preservation but equally on its extraction and interpretation. This requires not only the contextualization

\footnotetext{
${ }^{25}$ E.g., Gallivan and Wilkins 1997.

${ }^{26}$ E.g., Gardner and Wiedemann 1991, esp. 47-66; Barrett 1997.

${ }^{27}$ Hope 1997.

${ }^{28}$ Cf. Wallace-Hadrill 1994, 11.

${ }^{29}$ Carandini 1990.

${ }^{30}$ Boak and Petersen 1931; Husselman 1979.

${ }^{31}$ See, e.g., Meadows 1999.
} 
of artifacts but also careful attention to site formation processes and use-wear, residue, and microdebris analyses. The contextual data necessary for a study of domestic behavior are often unavailable as primary data because of a lack of careful documentation during past excavations. Often only interpretations, based on limited explorations of the archaeological record and outmoded scholarship, are all that is readily accessible to the investigator.

Even in more recent excavations of Roman domestic sites, issues concerning domestic space have received limited attention. For example, parts of the material cultural assemblages within the structural remains are often considered disturbed and therefore of little use in such investigations, being more informative on abandonment processes than on domestic behavior. ${ }^{32}$ For this reason, excavators have tended to remove loose finds and treat the remaining empty structures and any traces of decoration as the only physical remains appropriate for investigations of domestic behavior. ${ }^{33}$ Such finds are frequently decontextualized for typological studies, in accordance with the methodological traditions that still pervade much of Roman archaeology. ${ }^{34}$

\section{ANALYTICAL AND INTERPRETATIVE PROCEDURES}

Investigations of Roman domestic space frequently commence with an outline of the relevant evidence from ancient written sources and then interweave these fragmentary remains with the equally fragmentary material remains. This process often involves uncritical assumptions about the relationships between various types of textual data (e.g., architectural manuals, literary works, or histories), which have diverse agenda and sometimes anecdotal qualities. ${ }^{35}$ More importantly, situations in which both written and material remains of Roman domestic space are inextricably linked are extremely rare. Thus, most relationships of these two sources of evidence are essentially analogical. That is, evidence from one is used to simply interpret another, irrespective of the specificity of the contexts. For a more critical approach, each source can interrogate the other, the significance of their differences being a fundamental part of a more situated interpretation of each. The following discussion demonstrates how such procedures often compromise or misuse various sourc-

\footnotetext{
${ }^{32}$ For interpretations of such processes, see Schiffer 1996.

${ }^{33}$ E.g., Sackett 1992; Bruno and Scott 1993.

${ }^{34}$ Dyson 1995, 41-4; Allison 1997a.

${ }^{35}$ See Rawson 1997a, 91; Nevett 1997, 285-6; 1999, 1.
}

es of evidence and how these procedures themselves have often been misused.

\section{Labeling as Textual Analogy}

Following the tradition set by August Mau a century ago, ${ }^{36}$ the most widely used method for analyzing the material remains of Roman domestic space has been to first "ransack" literary sources for nomenclature for the individual spaces. ${ }^{37}$ Then, rather than employing this nomenclature as conventional labels, scholars have extrapolated spatial relationships of domestic furnishings, activities, and behaviors in so-labeled material contexts from the associated behaviors in the written contexts. Andrew Wallace-Hadrill advocated that "we must relate literary texts to archaeological remains in a more fruitful way." I could not agree more. Subsequent studies, however, generally continue to label the material remains in this manner, creating the fallacious perception that such labels are an integral part of the primary data. The point of departure for investigations of the material remains is invariably from such labeling.

Using Vitruvian or any other textual nomenclature to tie the activities in excavated domestic spaces to activities found in literary sources is a form of analogical inference. ${ }^{38}$ While this labeling of spaces can be a useful process for exploring the nature of past domestic behavior, it does not actually demonstrate that this label was used for this particular space in the Roman period, nor can it elucidate the activites that took place therein. Even an architect's labeled plan of a recently built house today does not dictate the activities that will take place in its spaces; rather, this labeling provides a technical convention. As it is not part of the primary dataset, but is essentially interpretative, any extrapolation about spatial aspects of social behavior becomes subjective. Without careful assessment, in each case, of the validity of applying terminology from one context to the conceptual framework of another, the result is a very prescriptive and unifying approach to an aspect of past human behavior that, in all probability, had been much more fluid and diverse.

For example, Jens-Arne Dickmann set out to investigate the transformation of domestic space in Pompeii from the second century B.C. to the first century A.D. and particularly the role of the "peristyle" in this transformation. ${ }^{39}$ In this he accepted

\footnotetext{
${ }^{36}$ Mau 1899.

${ }^{37}$ Wallace-Hadrill 1994, 6; cf. Descoudres et al. 1994, 9 fig. 6.

${ }^{38}$ See Wylie 1985.

${ }^{39}$ Dickmann 1997, esp. 123.
} 
the traditional terms peristylum, ambulatio, and exe$d r a$ as the labels for specific spaces in Pompeian houses on the basis of their varying uses by Cicero, Varro, and Vitruvius. Like many scholars before him, he has used the behaviors that these authors ascribed to these terms to describe those activities that would have taken place within the excavated spaces of Pompeian houses. Leach found, however, that the term peristylum is used infrequently in Roman literature and predominantly in reference to public rather than private space. ${ }^{40}$ Notably, this term was not used by Pliny. ${ }^{41}$ As a further although perhaps minor point, Vitruvius had recommended peristyla in townhouses should be situated crosswise, ${ }^{42}$ presumably to the atrium or the main axis of the house, and that they be wider than they are deep. In almost all Pompeian houses, the colonnaded garden actually lay on the opposite orientation. This variation between the prescribed physical arrangement in the remaining written sources and the extant arrangement of the material remains should warn of a lack of perfect correlation.

Leach has also drawn attention to the paucity of the term exedra in the Latin sources. ${ }^{43}$ It was used mainly by Roman aristocrats to communicate their intellectuality, and in circumstances in which its physical characteristics also conflict with those of so-named spaces in Pompeian houses. Moreover, Dickmann actually cited Vitruvius's use of this label in a Greek house ${ }^{44}$ to identify its location in Roman houses. ${ }^{45}$ Given the complexity of the relationships between these two cultures' domestic practices and current perceptions on the cultural identity of Pompeians, this is a seemingly inappropriate cross-cultural approach.

In his commentary on Pliny's descriptions of his country villas, Reinhard Förtsch approached relationships between these and the material remains in a similar manner. ${ }^{46}$ His study included a careful analysis of the types of rooms to which Pliny referred, concluding that his descriptions seldom inform either on the forms of the spaces or on the lived experiences that took place within them. ${ }^{47}$ Förtsch then devoted the greater part of his study to using extant spaces in the material remains, already labeled with Vitruvian nomenclature, to elucidate the physical

\footnotetext{
${ }^{40}$ Leach 1997, 59.

${ }^{41}$ See Förtsch 1993, esp. 85-93.

${ }^{42}$ De arch. 6.3.7.

${ }^{43}$ Leach 1997, 61-2.

${ }^{44}$ De arch. 6.7.3.

${ }^{45}$ Dickman 1997, 123.

${ }^{46}$ Förtsch 1993.
}

plans for Pliny's villas. ${ }^{48}$ In other words, it is in fact textual nomenclature that Förtsch used for his elucidation of Pliny's villas, not the material remains.

These two examples highlight how such nomenclature is often treated as if it were part of the material context. Dickman even referred to this nomenclature as "archaeological term[s]." ${ }^{49}$ Indeed, he employed them as archaeological conventions for identifying particular domestic spaces in the material record; however, his descriptions of activities within so-labeled spaces indicate that he also saw these terms as an intrinsic part of this record. Thus, his article and Förtsch's studies exemplify current, uncritical approaches both to interrelationships between written and material sources and to past scholarship.

If labels taken from written sources are anywhere useful for informing on domestic practice within the material remains, the epigraphical evidence in Pompeii would seem one of the richest resources. This resource, however, has generally been exploited for study in manners that are inappropriate either to the context of particular inscriptions or their specific functions. Matteo Della Corte's attempts to use mainly electoral programmata to identify the owners of Pompeian houses have been shown to be largely of his own fabrication. ${ }^{50}$ In reality very few Pompeian houses can be associated with named individuals as owners or occupiers. For example, the archive of waxed tablets found four meters above the garden in the so-called Casa di Caecilius Iucun$d u s$ has been used to identify a L. Caecilius Iucundus as a principal occupant of this house prior to A.D. 62. ${ }^{51}$ Caroline Dexter has argued, however, that despite the 24 Caecilii named in the tablets, ${ }^{52}$ there is no evidence that any had been occupants of this house. And even if there were, the information contained in these tablets concerns business transactions outside the household rather than anything pertaining to domestic life within.

More relevant Pompeian inscriptions here are those painted outside the Praedia Juliae Felicis and in the Insula Arriana Polliana, which did name the owners of these properties and also advertised areas available for rent within them. Both inscriptions used similar terms, with which we have some famil-

\footnotetext{
${ }^{47}$ Förtsch 1993, 26.

${ }^{48}$ Förtsch 1993, 30-134.

${ }^{49}$ Dickman 1997, 123. Cf. Tilley's discussion (1999, 82-101) on the archaeological term "megalith."

${ }^{50}$ Della Corte 1965. See Mouritsen 1988, 3-27.

${ }^{51}$ E.g., Dexter 1974, 187.

${ }^{52}$ Dexter 1974, 235.
} 
iarity through their occurrence in ancient texts, respectively: tabernae cum pergulis, cenacula equestria, domus; and balneum venerium, tabernae pergulae, cenacu$l a$. These inscriptions have been most recently treated by Felix Pirson. ${ }^{53}$ As he rightly acknowledged, these two inscriptions are rare occasions where such epigraphical evidence was associated with the physical remains of dwellings. The task that Pirson attempted, appropriately, was to assess the relationships between the inscriptional and physical evidence. While the relationship between the physical remains of the Praedia Juliae Felicis and the inscriptional reference to its balneum venerium seem self-evident, in both complexes this is less straightforward for tabernae and cenaculae.

As evidence for the physical characteristics of these specific spaces was not provided in the inscriptions themselves, Pirson's first task should have been a rigorous analysis of references in the ancient texts for the possible range of these terms and their contexts, particularly any clues as to the physical characteristics of so-named spaces. Alternatively, he might have provided references to studies where such analyses have been carried out. ${ }^{54}$ Instead, Pirson ${ }^{55}$ cited secondary sources first published in $1856,{ }^{56}$ and Gassner's thesis on Pompeian shops, ${ }^{57}$ as baseline data for identifying tabernae cum pergulis as workshops or shops with a mezzanine, possibly inhabited, and cenacula as upstairs apartments. Gassner's discussion on ancient references to the term tabernae, however, indicated that so-named areas had fairly wide-ranging functions, and none of the references she cited gave clues as to any specificity of their appearance. ${ }^{58}$ Neither did Gassner provide any specific reasons for using this term for particular spaces excavated in Pompeii. Both she and Pirson appear to have accepted, uncritically, 19th-century sources that also provided no evidence of any primary investigation to substantiate assumptions about relationships between textual nomenclature and the material culture. ${ }^{59}$ Johannes Overbeck would fall into Wallace-Hadrill's category of text-ransacking scholars, applying labels to spaces in Pompeian houses. ${ }^{60}$ Even so, he did not actually use the term taberna for a shop or indeed cenaculum for upper floors in Pompeii.

\footnotetext{
${ }^{53}$ Pirson 1997, 165-81.

${ }^{54}$ Leach (1997) carried out this type of analysis but notably not for taberna or cenaculum.

${ }^{55}$ Pirson 1997, 165-6.

${ }_{56}^{56}$ E.g., Overbeck 1856.

${ }^{57}$ Gassner 1986
}

Rather than taking a critical perspective on past scholarship, Pirson combined primary and secondary information to argue that, because some ancient sources indicated that tabernae could be "humble dwellings of the poor," ${ }^{61}$ tabernae in Pompeii, and particularly tabernae cum pergulis, would have been workshops with living spaces. He further corroborated this conclusion with "archaeological evidence for the habitability of tabernae." This constitutes a circular approach to the evidence, using analogy as original data. As far as I know, there is no "archaeological evidence" for the physical characteristics of "tabernae," as no excavated space can be labeled a taberna without recourse to textual analogy. So, there is no evident primary analysis in Pirson's interpretation of the meaning of taberna in this inscription. Rather, we can only conclude from the literary evidence that the term may have had a number of meanings, pertaining to the working and habitation spaces of people of limited means. This makes it extremely difficult to apply the label, as it appears in this inscription, to a specific space or spaces in this insula with any reliability. The assumption, held by Pirson, that the term cenaculum referred to the upper floor is based primarily on Varro's definition, ${ }^{62}$ ignoring Mau's century-old caution on Varro's etymology. ${ }^{63}$ As Varro's discussion was on the original location of this space and on the origin of this word, its meaning may have changed by the time of his writing. The written sources cited by Pirson, and the expression cenacula equestria indicate that cenacula had a variety of meanings. It is therefore extremely difficult, if not impossible, to locate the actual space in this insula that the inscription is advertising as rentable.

These inscriptions are certainly very helpful in informing us of the types of labels used for what were probably residential spaces in Pompeii. Pirson might indeed be correct in his identification of the spaces referred to in these inscriptions. His arguments, however, have used unsubstantiated secondary sources, circularity, and analogical inference as primary evidence. They are also based on the assumption that rental accommodation, of necessity, required entrances that were separate from the main dwelling. Conversely, Lisa Nevett has used the written evidence to point to separate entrances

\footnotetext{
${ }^{58}$ Gassner 1986, 1-7.

${ }^{59}$ See also Anderson 1997, 326-36.

${ }^{60}$ Overbeck 1856, 189-270.

${ }^{61}$ Pirson 1997, 168.

${ }^{62}$ Pirson 1997, 169.

${ }^{63}$ Mau 1899, 267-8.
} 
not being an essential characteristic of rented apartments. ${ }^{64}$ Indeed, Pirson's study has not "produce[d] valuable material for the evaluation of the significance of small, self-contained dwellings or apartments within the domestic architecture of Pompeii." ${ }_{65}$ A precise relationship between the inscriptions and particular parts of the physical remains is conjectural. More critical analyses of the terms used in the inscriptions and of their variety of applications are needed. In addition, separate analyses of the patterns of similarity and variability of the physical remains are also required ${ }^{66}$ More honest articulation of the range of possible relationships between the different sets of data may provide more reliable information on the spatial settings of rented accommodation in Pompeii.

This type of Latin labeling is considered to be more difficult for excavated domestic spaces beyond the Italian peninsula. Many scholars still believe that "[h] ouses known from Pompeii and Herculaneum illuminate [Vitruvius's] descriptions." ${ }^{67}$ For this reason, Yves Thébert struggled to allocate Vitruvian nomenclature to spaces in houses from Roman North Africa, whose ground plans bore no resemblance to those in these Italian cities. ${ }^{68}$ Conversely, J.T. Smith's attempts to assign functions to spaces in villas in the western provinces indicate an awareness that the labels found in the Roman written sources may not be appropriate for dwellings built and occupied by people whose social and cultural milieu probably bore little resemblance to those writing such texts. ${ }^{69}$ Even if such terms were used by people in the provinces or North Africa, the so-labeled rooms may have borne little structural or functional resemblance to any Italian counterparts.

In summary, textual nomenclature from certain ancient authors is often allied with anecdotal information from others to gain insights into the spatial division of household activities in extant structural remains of Roman period houses. This very combination has produced an impression that we are wellinformed about Roman domestic life. On the contrary, recent approaches to such labels show that this is an oversimplification. Through the analysis of the occurrences and contexts of this nomencla-

\footnotetext{
${ }^{64}$ Nevett 1997, 296.

${ }^{65}$ Pirson 1997, 166.

${ }^{66}$ Steven Ellis (Ph.D. candidate, University of Sydney) is currently investigating some of these types of spaces in Pompeii.

${ }^{67}$ Anderson 1997, 289.

${ }^{68}$ Thébert 1987.

${ }^{69}$ Smith 1997.

${ }^{70}$ Leach 1997.
}

ture in Latin texts, Eleanor Leach has questioned the appropriateness of traditional associations of such labels with the extant physical remains and with specific domestic activities. ${ }^{70}$ These associations stem from an overreliance on Vitruvian terminology that is being used as a type of Linnaean classification system by modern scholars. ${ }^{71}$ The apparent conflicting use of certain terms by Vitruvius and Varro should exemplify their inappropriateness as labels to indicate specific domestic behavior. For example, Riggsby's analysis of the use of the term cubiculum, in pursuit of a concept of "privacy" in the domestic realm, highlights the multiple meanings of this label. ${ }^{72}$ Unfortunately, he reverted to traditional approaches by assuming that such cubic$u l a$ have indeed been identified in the material remains. $^{73}$

\section{Architectural Typology}

Studies in the Roman world beyond the Italian peninsula rely more heavily on the archaeological investigation of the material remains and less on the ancient written evidence. Typology, a fundamental approach in archaeological scholarship, ${ }^{74}$ has played a major role in investigations of domestic space in regions whose study has been less dependent on traditional classical scholarship. ${ }^{75} \mathrm{Be}-$ cause of the nature of the evidence, and past approaches to it, many scholars have restricted their investigations to the study of two-dimensional ground plans of houses. While more material remains might once have been preserved (e.g., some of the decoration and contents, including organic residues), the kinds of contextual information needed for a study of domestic behavior has seldom been careful collected. Thus when the conventional textual nomenclature cannot be applied to such house plans, and all other data are lacking ${ }^{76}$ investigators of domestic behavior have been largely limited to a study of ground plans and possibly floor types.

This is exemplified by Smith's study, ${ }^{77}$ which used evidence for continuity and change in the ground plans of villas in the western provinces to investigate their development and their cultural and social con-

\footnotetext{
${ }^{71}$ See also Allison 1999a.

${ }^{72}$ Riggsby 1997.

${ }^{73}$ Riggsby 1997, 42.

${ }^{74}$ See Johnson 1990.

${ }^{75}$ Although see also Nevett 1999, 22.

${ }^{76}$ Cf. Kleiwegt 1999, $20 \mathrm{March}$, esp. para. 1, http:// ccat.sas.upenn.edu/bmcr/1999/1999-3-20.html.

${ }^{77}$ Smith 1997.
} 
texts. While this is a long-accepted method, it limits the types of inquiries to which this data can be subjected. Nevertheless, Smith attempted to identify activities that took place in various spaces within these villas $^{78}$ and household relationships,${ }^{79}$ through the size of these two-dimensional spaces, their associations with other spaces, and sometimes the remains of fixtures such as hearths. While some of his attributions are highly probable, many are based on an intuitive or "common sense" approach to spatial function rather than on physical evidence or any apparent theoretical framework concerning past domestic practice. For example, he identified a large number of small narrow rooms as lobbies (e.g., Eckartsburm between rooms 7 and 8). ${ }^{80}$ Given that these ground plans are often drawn from foundations only and, therefore, that evidence for thresholds is frequently lacking, ${ }^{81}$ such specific functional identifications seem unjustifiable. For example, rooms in Pompeian houses with seemingly comparable proportions and locations (e.g., rooms $\mathrm{k}$ and $\mathrm{l}$ in the Casa di Giuseppe II $)^{82}$ can be definitively identified as storerooms. I am not proposing that the rooms in the Eckartsburm villa were storerooms. Rather it is extremely subjective to interpret the domestic behavior in these villas through room functions for which there is no specific evidence.

Similar architectural typology has also been used in Roman Italy. A two-dimensional and typological approach was taken by Wallace-Hadrill to investigate relationships between Pompeian houses. ${ }^{83} \mathrm{He}$ classified these houses by size and numbers of rooms to assess the social status of their inhabitants, or more specifically of the "householders." In a similar fashion, Grahame investigated the spatial relationships within individual Pompeian houses by outlining the interrelationships of open and closed areas and through-routes in Pompeian houses. ${ }^{84}$ Wallace-Hadrill is fully aware that this is a limited approach to a rare example where not only three-dimensional houses survive intact but also where much information about their decoration and contents is available. Such familiarity with the physical remains is not apparent in Grahame's study, however, in which conclusions about gradations of privacy are somewhat unsurprising.

The typology of structural remains can, therefore, make only a limited contribution to a better understanding of Roman domestic spatial behavior, with-

\footnotetext{
${ }^{78}$ Smith 1997, 15-6, 26, passim.

${ }^{79}$ Smith 1997, 36-7, 45, passim.

${ }^{80}$ Smith 1997, fig. 25.

${ }^{8}$ See Scott 1990, 170.
}

out recourse to other evidence or theoretical frameworks. It can indeed produce broad concepts of household wealth or generalized spatial functions such as through-routes, restricted, or unrestricted space. But identification of areas for formal or utilitarian activities, or who is restricted and who is not, requires more specific contextual information and a critically cross-cultural approach to all the potential possibilities for such household organization and interrelationships. For example, typological analyses are often predicated on a premise that there was a master plan in the construction of Roman domestic space that subsumed traditional practice. Smith is indeed aware of traditional practice but seems to be overwhelmed with a belief in a master plan from which individual houses have deviated. Thus, employers of typology must be conscious of the normalizing effect of their analyses on past human behavior.

\section{Architectural Typology Combined with Labeling}

As discussed above, the limited applicability of spatial typology in approaches to domestic practice has led scholars, particularly those with more literary backgrounds, to use textual nomenclature as if it were part of material evidence. Typologies of the structural remains are then developed that are grounded in this nomenclature. Perhaps the most obvious and frequently used examples where architectural typologies have been entwined with textual nomenclature as primary data are studies that concern Roman houses labeled as atrium houses or peristyled houses.

It has long been widely accepted that the type of courtyard house that featured prominently in Pompeii was the "typical" Roman house described by Vitruvius. This acceptance is somewhat surprising considering that Pompeii was a provincial town in the heavily Greek-influenced southern part of Italy, and it did not come under Roman domination until some 500 years after it became a walled city and some 200-300 years after the construction of its first so-called atrium houses. ${ }^{85}$ It is less surprising, however, when one considers the significant role that Pompeii has played in studies of Roman domestic architecture over the last century.

Recent studies commenced their investigations of the development of this Pompeian courtyard house by first labeling its various parts with Vitruvi-

\footnotetext{
${ }^{82}$ Allison 1992a, 437; forthcoming

${ }^{83}$ Wallace-Hadrill 1994, 66-90.

${ }^{84}$ E.g., Grahame 1997, 137-64.

${ }^{85}$ See, e.g., Ling 1997, 131-2.
} 
an nomenclature and then discussing the changing relationships between so-labeled spaces. ${ }^{86}$ Most pertinently, Wallace-Hadrill investigated house plans from Marzabotto, Cosa, Fregellae, Tolve-Moltone, and Pompeii to trace the development of the "Roman atrium house" in Italy. ${ }^{87} \mathrm{He}$ criticized past scholarship for having been "reliant on hypotheses or simply mere assumptions uncontrolled by close study." His paper is a carefully organized argument demonstrating that the term atrium could have been used for a far greater range of house types, particularly those with completely open courtyards, than has traditionally been assumed. He discussed the house plans at sites in terms of their similarities to and differences from "the canonical atriumhouse of Pompeian type." 88 Thus, like many previous scholars, he assumed that the covered courtyard, or front hall, and surrounding rooms of Pompeian houses provide the prototype for identifying atrium-houses at other Italian sites. Any variations are seen as deviations from that prototype. Thus, despite Wallace-Hadrill's attempts to break free of the assumptions of the scholars he has critiqued, he similarly argued from the perspective that Vitruvius provided an archetypal Roman house whose plan is realized, most perfectly, at Pompeii. Other excavated house plans, both at Pompeii and elsewhere in Italy, are seen as deviations whose variation must be explained in relationship to the terminology provided by Vitruvius, that is, tablinum, fauces, ala, etc.

Modern scholars seem to have used the label atrium more consistently for such courtyards, largely because Vitruvius used it more consistently. Interestingly, the term cavum aedium is rarely used, perhaps because it is more generic. Leach questioned the suitability of the term "atrium" for houses such as those known to us in Campania. ${ }^{89}$ Indeed, Vitruvius appears to have used the two terms interchangeably. ${ }^{90}$ He seems to have used the term atrium for a specific space, particularly when referring to the rooms that opened off it; ${ }^{91}$ however, he prescribed that uninvited visitors could enter the cavum aedium. ${ }^{92}$ Varro discussed the derivation of these two terms. ${ }^{93}$ He gave no indication of the relationship between them or any information on the locations, forms, or functions of an atrium. He described the cavum aedium as having been roofed but with an open internal space for communal use and surrounded by various different rooms. ${ }^{94}$ The terms that Varro used for the rooms around the cavum aedium were quite different from those used by Vitruvius for the rooms surrounding the atrium. Although Pliny's Laurentine villa had both an atrium and a cavum aedium, ${ }^{95}$ Förstch appears to have downplayed the latter term in his archaeological commentary. ${ }^{96}$ As indicated by his plan of a Roman house, which was independent of influence from the Pompeian evidence but which appeared to combine Vitruvian ideals with Pliny's description, W.A. Becker believed that a large Roman house would have had a colonnaded atrium preceding the cavum aedium. ${ }^{97}$

Wallace-Hadrill argued that the construction of typologies as a categorization system for modern scholars obscures ancient social reality. ${ }^{98}$ In his attempts to isolate some developmental principles of Roman houses, however, he would have been better served by employing such categorization and its chronological significance than by trying to unravel the chronological and spatial relationships of the parts of Roman Italian houses through assumptions that Vitruvian labels will assist in isolating spatial components, their developments, and intersite relationships.

This labeling seems also to have been a problem in Fabrizio Pesando's study of the development of early Pompeian houses. ${ }^{99}$ Pesando organized his sample typologically, according to whether the houses had a "peristyle" or a "hortus." The house plans with which he illustrated his study suggest that it was these labels, rather than the physical remains, that provided these distinctions. For example, of the houses that he classified as "Case ad atrio e peristilio," two of the gardens have no apparent colonnade (the Casa di Criptoportico $^{100}$ and Casa della Nave Europa ${ }^{101}$ ) and three have a partial colonnade or "pseudo-peristyle" (the Casa del Toro, ${ }^{102}$ Casa di Pansa, ${ }^{103}$ and Casa di Julius Polibius ${ }^{104}$ ). It is unclear why the gardens of the latter three, par-

\footnotetext{
${ }^{96}$ Förstch 1993.

${ }^{97}$ Becker 1876, 234 plan A (hence Allison 1994, 83 fig. 50).

${ }^{98}$ Wallace-Hadrill 1997, 222; cf. Mar 1995.

${ }^{99}$ Pesando 1997.

${ }^{100}$ Pesando 1997, fig. 3.

${ }^{101}$ Pesando 1997, fig. 10.

${ }^{102}$ Pesando 1997, fig.11.

${ }^{103}$ Pesando 1997, fig. 16.

${ }^{104}$ Pesando 1997, fig. 36.
} 
ticularly of the Casa del Toro, are typologically different from the "pseudo-peristyles" in the Casa del Sacerdos Amandus ${ }^{105}$ and the Casa di Sallustio, ${ }^{106}$ houses that Pesando classified as "Case ad atrio e hortus." Also, why is the garden of the Casa della Nava Europa typologically different from that of I, 20,4? ${ }^{107}$ It is equally unclear why Pesando has classified the Casa di Ceii as a "casette proviviste di hortus" when it has an "atrium." Generally, the differences between Pesando's three types seem to be based on house size and confusion between the labels for architectural types and the functions of such spaces. Again, his study may have been more useful if he had carried out a separate typological investigation of these houses and the variations in their garden plans and specific architectural features without recourse to Latin nomenclature.

Michele George explored written sources to outline the major groups of players and their behaviors within the domestic world, commendably stressing a need for an awareness of the relationships between occupants and guests and between free occupants and slaves. ${ }^{108}$ However, she then articulated the use of the spaces in Pompeian houses by their various occupants through the application of Vitruvian labels to these spaces rather than through anything intrinsic evidence in the physical remains beyond potential hierarchies of spatial arrangements. While her argument for differences in domestic behaviors in Pompeian and North African houses used typological comparisons between the architectural arrangements in both areas, it stems, fundamentally, from the practice of labeling the central courtyards in houses at Volubilis as peristyles. ${ }^{109}$

To argue for the widespread occurrence of "the so-called axial peristyle house," Katharina Meyer also followed the traditional practice of labeling the central courtyards in houses of the western empire as peristyles. ${ }^{110}$ She also labeled the front halls or forecourts vestibula and spaces beyond the courtyard triclinia. It was more through the application of such nomenclature than through architectural variation that Meyer identified activities and their associations with these spaces and sought to relate these spaces to those of so-called atrium houses of earlier periods in Italy, particularly those excavated in Campania. ${ }^{11}$

\footnotetext{
${ }^{105}$ Pesando 1997, fig. 38.

${ }^{106}$ Pesando 1997, fig. 43.

${ }^{107}$ Pesando 1997, fig. 41.

${ }^{108}$ George 1997a.

${ }^{1099}$ George 1997a, 311-6; see Thébert 1987, esp. 357-64.

${ }^{110}$ Meyer 1999.

${ }^{111}$ Meyer 1999, esp. 108-15.

${ }^{112}$ Cf. the Casa del'Atrio corinzio in Herculaneum (De Vos and De Vos 1982, 288) and Casa dei Dioscuri in Pompeii (Rich-
}

The central courtyards in these houses can undoubtedly be labeled peristyles, according to scholarly convention, because they tend to have columns, and usually more of them than the so-called atria in Campanian houses, although not always. ${ }^{112}$ It has already been observed, however, that the term peristyle was rarely applied to Roman domestic space in the written sources. Meyer suggested that the triclinia in these peristyled houses could be identified "ideally" through marks in the pavements that indicate the placement of banqueting couches. ${ }^{113}$ Nevertheless, she does not appear to have managed to do this. ${ }^{114}$ It is perhaps noteworthy that plans of such houses bear a remarkable resemblance to Becker's original hypothetical plan of a Roman house that stemmed, at least in part, from Pliny's description. ${ }^{115}$ While the contemporaneity of Pliny's Laurentium with the house plans discussed by Meyer might render this a suitable parallel, Becker's labeling of the spaces diverges from hers. His atrium is her vestibula, his cavum is her peristyle and his tablinum is her triclinium. While Becker's house plan is probably hypothetical, my question is what evidence does Meyer have that makes her terminology more appropriate for these house plans than his?

It is unreasonable to assume that a courtyard in other parts of the Roman Empire was or was not called an atrium on the basis of its similarity to or difference from a so-called Pompeian atrium house. As mentioned above, Yvon Thébert worked from the premise that the courtyards found in Roman period houses in North Africa were not atria because they did not look like so-labeled spaces in Pompeii. ${ }^{116}$ As we have no primary data for the label for these spaces in either context, we cannot use the material evidence from Pompeii as evidence for labeling the spaces in North African houses. Indeed, the notated house plan on the Oxyrhynchus papyrus ${ }^{117}$ identified an atreion (Greek = atrium) that bears little structural or locational relationship to so-called atria in Pompeian houses. Despite this, in a similar line of reasoning to that of Thébert, Richard Alston argued that the house "is not recognisable as an atrium house." Surely this anciently labeled plan is a better indication of the character of such an artifact than is

\footnotetext{
ardson 1955, pl. 1).

${ }^{113}$ Meyer 1999, 114.

${ }^{114}$ Although see Dunbabin 1996, 72-4.

${ }^{115}$ Cf. Becker (1876, 234 plan A) with Meyer (1999, 103 fig. 2). It is conceivable that Becker's Roman house plan was inspired by such remains, rather than the Campanian ones that were largely unknown at the time of his writing.

${ }^{116}$ Thébert 1987, 325-6.

${ }^{117}$ See Alston 1997, 29-30 fig. 1.
} 
any analogical inference at Pompeii. Surely it should act as a prompt for "rethinking [modern perceptions of] the Roman atrium house." 118

There is certainly some correlation between ancient textual descriptions of an atrium and the ground plans of many excavated houses. To date, however, any relationship between the two is analogical, not intrinsic. The issue is that, after labeling certain Italian buildings atrium houses, scholars often use this labeling as the basis for an assessment of the development of the atrium. A less analogically confused method would be to first study the range of the material evidence through standard processual and material cultural approaches, independent of such labeling. ${ }^{119}$ It might then be pertinent to assess whether or not the term atrium and its meanings in the written sources are relevant to the evidence provided by this complete material record. ${ }^{120}$ This will require more intensive study of the archaeological reports and probably also excavation that pays heed to such issues, particularly of pre-A.D. 79 levels of Pompeii ${ }^{121}$ and of micro-debris, but such excavations should not use textual labels as baseline data. Because the Pompeian house plan is so etched in people's minds as the Roman atrium house, it has been assumed that an excavated courtyard was or was not called an atrium on the basis of its similarity to or difference from a Pompeian atrium house.

In summary, typologies of Roman house plans without Vitruvian nomenclature, which was in fact rarely used in Latin literature, ${ }^{122}$ might be more useful as a first step, for Italy as well as for the provinces. This was intimated by Wallace-Hadrill, despite his use of such nomenclature as the basis for his discussion. ${ }^{123}$ While it is extremely convenient for archaeologists and social historians to use such terms conventionally, the use of Vitruvian nomenclature also presupposes that Vitruvius's authority on the principles that governed all builders and occupiers of such houses is above questioning, despite his apparent lack of success "in his chosen profession." 124

\section{Decorative Typologies and Iconographies}

Where relevant remains are available, decorative typologies (i.e., of wall paintings and floor mosa-

\footnotetext{
${ }^{118}$ Wallace-Hadrill 1997.

${ }^{119}$ Such an approach has been explored for a sample of Pompeian houses: see Allison 1997b, forthcoming, ch. 5.

${ }^{120}$ See also Allison forthcoming, ch. 7.

${ }^{121}$ See Bon and Jones 1997, 5; Fulford and Wallace-Hadrill 1998, 128-30.

${ }^{122}$ Leach 1997.

12:3 Wallace-Hadrill 1997

${ }^{124}$ Anderson 1997, 43.

${ }^{125}$ E.g., Corlàita Scagliarini 1974-1976; Barbet 1985.
}

ics) have often been incorporated with architectural typologies to elucidate functional criteria for domestic spaces. The most significant and useful approach in this regard is based on an observed correspondence between divisions in the decorative schemes of walls and floors and the type and possible use of space. ${ }^{125}$ In the publication of a specialist wall-painting conference held in Amsterdam in 1992, many of the papers discussed how the decoration in particular spaces was organized according to the architectural type of a room or space. ${ }^{126}$ Despite the title of that book, few of the papers dealt with functional analyses, the exceptions being the more obvious cases where fixtures have provided clues to room use, such as Gemma Jansen's study of latrines or Natalie de Haan's of bath suites. ${ }^{127}$ In other papers functional analyses were founded, somewhat predictably, on the application of textual nomenclature to material remains. ${ }^{128}$ Nonetheless, this volume furthers our understanding of the fundamental relationships between architectural and decorative typologies in Roman domestic spaces and provides the groundwork for such analyses in the future.

While there are observed associations between architectural and decorative typology in the material remains, ${ }^{129}$ and prescribed ones between room use and decorative typology in textual sources, ${ }^{130}$ for the most part specific links between decorative typology and room use have not yet been rigorously and comprehensively explored. Significant steps have, however, been taken by Katherine Dunbabin who, in her study on the social importance of dining, argued that "[s]ecure identification of rooms for dining is only possible under exceptional circumstances." "131 She followed the widely accepted approach of Corlàita Scagliarini, arguing that dining spaces can only be identified through decorative schemes that distinguish the dining area from an antechamber or indicate the location for moveable couches, or through the presence of fixed masonry couches. Rooms without such indicators had "a more flexible use."132 I suggest that rooms evidently designed for moveable couches and tables may also have performed other functions when necessary, particularly in different seasons. ${ }^{133}$ This

\footnotetext{
${ }^{126}$ Moormann 1993.

${ }^{127}$ Jansen 1993; de Haan 1993.

${ }^{128}$ E.g., Tybout 1993; Eristov 1993.

${ }^{129}$ Corlàita Scagliarini 1974-1976; Barbet 1985; see also Allison $1992 \mathrm{~b}$.

${ }^{130}$ E.g., Vitr. De arch. 7.4.

${ }^{131}$ Dumbabin 1996, 67.

${ }^{132}$ Dunbabin 1996, 70.

${ }^{133}$ Allison 1992a, 54-5, 62-6; forthcoming, ch. 6.
} 
must surely be true of the great salons in houses of the high empire in the western Mediterranean. ${ }^{134}$ Dunbabin has paid close attention to the literature and the material remains to develop an understanding of domestic practices and their changes over time, although it is also important to acknowledge that the domestic practices she highlighted do not, of necessity, exclude others.

As has been evident to numerous scholars, ${ }^{135}$ and most recently articulated by Wallace-Hadrill, ${ }^{136}$ there is undoubtedly a connection between the elaboration of a room's decoration and the formal or utilitarian nature of its function, visibility, or privacy. Jansen's study of latrines, however, has admirably demonstrated that the level of embellishment is not consistent for a particular room type across a range of houses. ${ }^{137}$ The context of each decorative scheme, not only the type of room but also the type of house and the room's relationships with others in the house, is important to any assessment of a room's use or status through its decorative scheme. While relationships between decorative schemes and room layout are evident, it is extremely difficult to identify any formulaic relationship between decoration and room function.

The iconography of decorative schemes is also often considered to be related to the activities that took place in the spaces so decorated. For example, the walls of Pompeian garden areas frequently are decorated with large garden scenes, animal hunts, or landscapes alluding to perceived relationships between these often very small gardens and activities that take place in wild or exotic places. ${ }^{138}$ In comparison with the decoration in other parts of the house, there exists a strong associational sense between such paintings and open garden areas. At the same time, not all garden paintings are associated with open and airy spaces. The walls of small, enclosed rooms in the Casa del Frutteto in Pompeii were decorated with some of the finest garden paintings in the houses. ${ }^{139}$ Thus, as has been noted in some of the studies of garden paintings, the decorative iconography may not be intrinsically linked to the type of space or indeed to any activities carried out in a space, or these correlations may not be immediately comprehensible to the modern investigator.

\footnotetext{
${ }^{134}$ Dunbabin 1996, 73-4.

${ }^{135}$ E.g., Strocka 1975.

${ }^{136}$ Wallace-Hadrill 1994, esp. 155-69.

${ }^{137}$ Jansen 1993.

${ }^{138}$ See, e.g., Michel 1980; Andreae 1990; Fröhlich 1993; Zanker 1998, 184-90.

${ }^{139}$ Sichtermann 1974.

${ }^{140}$ Strocka 1993.

${ }^{141}$ Maiuri 1933, 84-9.

${ }^{142}$ Richardson 1988, 160
}

For example, V.M. Strocka's identification (1993) of a private library in house VI 17,41 in Pompeii relied heavily on the inclusion in this room's wall paintings of men wearing white tunics and wreaths and carrying scrolls. ${ }^{140}$ This proposal is indeed interesting and worthy of further investigation, but given the scarcity of comparable figures in Pompeian wall painting, it makes unvalidated assumptions about our comprehension of the roles of these wall paintings. As a precedent for the existence of such a room in these houses, Strocka took Amedeo Maiuri's identification of room 21 in the Casa del Menandro as a private library. ${ }^{141}$ Maiuri's identification is based on a painting of the figure of Menander on a nearby wall and on this room's furnishings, which combined an elaborate, off-center floor mosaic with roughly plastered walls showing evidence for shelving. L. Richardson jr. elaborated on this identification by proposing that the walls of this room originally would have had large wooden cabinets, later replaced by these shelves; ${ }^{142}$ however, there is no evidence for such cabinets. Rather, the room's furnishings and contents ${ }^{143}$ are witness to the room's changing use, probably from a more formal room of indeterminate function, which conceivably allowed for couches along the west and south walls, to a more general storage area. Specific evidence that rooms were set aside in Roman houses as private libraries is scarce. For example, as Förtsch has pointed out, Pliny's villa did not have a library as such but rather a cubiculum with one wall fitted with bookshelves, similar to a library. ${ }^{144}$

In a similar manner to Strocka, John Clarke identified a woman's room in the Casa dei Vettii in Pompeii and a child's bedroom in the Casa di $M$. Lucretius Fronto on the basis of the iconography of the figurative representations in the wall paintings. ${ }^{145}$ The wall paintings in the so-identified woman's room depict mythological women associated with motifs of love, and those in the child's room have moralizing scenes. These examples point to domestic behaviors and ideals better suited to 19thor 20th-century households, rather than to evidence in the written and material data concerning Roman households. Indeed, such identifications

\footnotetext{
${ }^{143}$ The finds in this room consisted of three ceramic lamps, part of a bronze lampstand, small glass vessels, a bronze pan, two ceramic lids, three bronze locking devices (probably from a chest), a lead weight, possibly melted glass, and unidentified blue organic powder. The findspots (with the possible exception of that of the lead weight) suggest that the material had been placed on the shelves.

${ }^{144}$ Förtsch 1993, 20.

${ }^{145}$ Clarke 1991, 157, 159.
} 
would produce a certain circularity of argument if used in analyses of the spatial divisions of domestic activities in the Roman world. Such iconographic studies are seemingly founded on modern analogy and thus make potentially misleading assumptions about concepts of individuality and about the lines of divisions in Roman domestic space. In general, a more thorough understanding is needed of the symbolic qualities inherent in these iconographic schemes, as well as of fashion dictates, before their relationship to household activities can be investigated. ${ }^{146}$

\section{Modern Analogy}

Richard Reece argued that the interpretation of material remains is generally carried out through the use of analogy. ${ }^{147}$ For example, we often assume that large Roman houses were occupied by large numbers of closely associated people and owned by at least one important and wealthy male, because large houses in more recent times are generally occupied by large numbers of people and owned by wealthy and important people, usually male. ${ }^{148}$ While this analogy may be at least occasionally correct, it is merely analogy and not fact. As such its use as a basis for further interpretation risks a certain amount of subjectivity. Indeed, parts of such an analogy can be disproved for Pompeii. For example, epigraphical evidence indicates that one of the largest residential and commercial establishments, the Praedia Juliae Spf. Felices (the properties of Julia Felix the daughter of Spurius), was owned by a woman who rented out parts of it, ${ }^{149}$ including baths, shops with lofts, and second floor apartments. ${ }^{150}$

Wallace-Hadrill used modern analogy to identify "axes of differentiation" in his investigation of social differentiation in Roman domestic spaces. ${ }^{151}$ His dismissal of an analogical relationship between the spatial distinctions in Roman houses and separate children's areas in grand country houses of 19th-century England is probably appropriate, although his reason for this dismissal-that this was associated with the lack of social identity of Roman children-can be shown to be unjustified. ${ }^{152}$ Instead, Wallace-Hadrill emphasized Vitruvius's apparently obsessive concerns with social rank to di-

\footnotetext{
${ }^{146}$ See Allison 1997c.

${ }^{147}$ Reece 1993.

${ }^{148}$ But see Smith 1997, 4; Nevett 1999, 31-2; cf. Kleijwegt 1999.

${ }^{149}$ Della Corte 1965, 821; Pirson 1997, 179 n. 49.

${ }^{150}$ Parslow 1995, 12.

${ }^{151}$ Wallace-Hadrill 1994, 8-16.
}

vide the house along public/private and grand/ humble axes. To add weight to such divisions he used analogies with houses of the nobility in 18thcentury France. I find this analogy interesting in its potential elucidation of ancient written information on domestic differentiation but I am concerned that it does not employ the material remains of Roman houses in this elucidation. Rather, it uses the authority of Vitruvius and lifestyle in the French ancien régime to explain behavior in Pompeian houses. In contrast, the physical remains of these houses, including the arrangements of their courtyards, distribution of wall and floor decoration, locations for food preparation and storage, and distribution patterns of the contents, point to much more complex spatial integration of domestic activities. ${ }^{153}$ Such analogies can best be used to explore relationships between modern and ancient behaviors rather than to explain them.

While Wallace-Hadrill may have dismissed the relevance of 19 th-century separate spheres' ideologies to Roman domestic space, this ideology and its inherent dichotomies seem fundamental to George's desire to identify slave areas in Roman houses. ${ }^{154}$ Anderson's approach to this subject, identifying "servile rooms" as those that are located away from the main axes of the house and therefore demonstrating that "servants would be seen as little as possible," is circular. ${ }^{155}$ As George concluded, neither the material nor the written remains points to an existence of or a need for separate servile spaces in Roman houses. ${ }^{156}$ Rather, the pursuit of such an inquiry stems from an "out of sight" mentality towards slaves, which, to my mind, is imbued with Victorian ideals. That George did not articulate this as an analogy to be explored is perhaps indicative that similar perspectives often constitute inherent biases in many investigations of past domestic behavior.

Smith did explore relationships between the spatial arrangements of Roman villas and Medieval and post-Medieval houses in an attempt to identify the patterns of social behavior within these villas. ${ }^{157}$ Unlike Wallace-Hadrill, he did not draw on one model to explain this social behavior but noted the complexity of the relationships between the models and the importance of understanding relation-

\footnotetext{
${ }^{152}$ Rawson 1997a, 1997b.

${ }^{153}$ See Dunbabin 1995, 390; Allison 1997b, forthcoming, esp. ch. 6 .

${ }^{154}$ George 1997b.

${ }^{155}$ Smith $1997,299-300$.

${ }^{156}$ George 1997b, 22-4.

${ }^{157}$ Smith $1997,15-8$.
} 
ships between suites of rooms. Marc Kleiwegt questioned his use of more recent, rather than contemporary, analogy. ${ }^{158}$ This later housing, however, located in what had once been the western provinces, is as likely to have been relevant to Smith's study as the material and written Roman sources to which Kleiwegt alluded. A more detailed exploration of the similarities and differences between contemporary textual analogy and analogies with later housing in the region might lead to a greater understanding of the relationships between all threeRoman villas in the provinces, textual evidence on Roman houses, and early Medieval housing.

Modern analogy, whether employed deliberately or subconsciously, can often provide extremely misleading perspectives on domestic behavior in the past. The use of specific analogies can normalize the perception that little has changed in the domestic domain over the past millennia. It belittles and can frequently obliterate the often fundamental changes to domestic conditions between ancient, Medieval, and post-Medieval worlds. Modern analogy can best be employed if it includes a range of examples and if it also explores, both critically and self-consciously, the range of difference and its significance.

\section{Contextualized Artifact Assemblages}

Invariably, archaeological studies of Roman domestic space consist of the investigation of the structural and decorative evidence of excavated spaces. Partly because of the great wealth of such remains, continuously being reanalyzed by different scholars from different perspectives, the full dataset of the material remains has generally received less consideration than in other branches of archaeology. Unless individual finds are particularly striking (e.g., sculpture in the garden of the Casa degli Amorini Dorati in Pompeii ${ }^{159}$ ), or illustrate domestic behavior articulated in ancient written sources (e.g., so-called arcae in Pompeian houses ${ }^{160}$ ), the nonstructural remains of Roman houses (i.e., moveable finds and residues) generally have been removed from their spatial contexts and used for specialist studies, ${ }^{161}$ or completely ignored. Only rarely have the provenance, distribution, and quantification of a dwelling's contents been used to throw light on

\footnotetext{
${ }^{158}$ Kleiwegt 1999, 20 March, para. 13, http://ccat. sas.upenn.edu/bmcr/1999/1999-3-20.html.

${ }^{159}$ See Seiler 1992, figs. 205-208.

${ }^{160}$ Cf. Allison 1999a, 60-1.

${ }^{161}$ See Allison 1997a.

${ }^{162}$ E.g., Roaf 1989; Daviau 1993; Ault 1994; Nevett 1999.
}

domestic behavior. While recent studies in many other branches of archaeology have been taking a more contextual approach to using artifact assemblages to investigate domestic behavior, ${ }^{162}$ the assemblages from Roman houses generally continue to be removed for typological studies in a traditional manner.

Studies that have incorporated house contents have tended to concentrate on sculptural remains, particularly those in garden and courtyard areas. For example, Eugene Dwyer investigated the sculptural remains in five Pompeian houses for their role in domestic contexts, and Richard Neudecker was also concerned with the social significance of sculptural display in Roman villas in Italy. ${ }^{163}$ Elaine Gazda's book widened these approaches by including studies on wall and floor decoration and on sculptural display to investigate the role of art in the domestic sphere. ${ }^{164}$ Dwyer included lists of other finds from the Pompeian houses in his study and used them in his interpretations of spatial function, ${ }^{165}$ yet his conclusions are largely dictated by the textual nomenclature applied to these spaces. Similarly, recorded finds are listed for each room in the series, Häuser in Pompeji, reiterating those published in the Notizie degli Scavi di Antichità. ${ }^{166}$ With the exception of sculptural remains, however, these lists have no impact on any functional or occupancy analyses in these volumes. A reason for the neglect of the mundane artifacts is that these predominantly art-historical investigations emphasize the display and prestige of works of art within the house rather than other aspects of Roman domestic life. Undoubtedly because of such emphases, my own paper on a database of Pompeian house contents, presented at the 1990 Archaeological Institute of America meeting in San Francisco, was included in a session entitled "Roman art in context."167

George compared the sculptural arrangements, fountains, and plantings in so-called atria and peristyles in Campanian houses to argue that, in these particular houses, "a strict separation between the kinds of decoration which suited the atrium and the peristyle no longer existed." ${ }^{168}$ But when did it exist? If the terms "atrium" and peristyle are being used as archaeological conventions then one would assume that there is archaeological evidence for

\footnotetext{
${ }^{163}$ Dwyer 1982; Neudecker 1988.

${ }^{164}$ Gazda 1991.

${ }^{165}$ Dwyer 1982, 113-20.

${ }^{166}$ E.g., Strocka 1984; Seiler 1992; Ehrhardt 1998.

${ }^{167}$ Allison 1991.

${ }^{168}$ George 1998, esp. 85.
} 
this change. George does not present such evidence. For example, evidence for the construction dates of fountains in so-called atria would appear to indicate that they were contemporaneous with their appearance in so-called peristyles. ${ }^{169}$ Indeed, any evidence she provides for the chronology of planters in atria argues against her hypothesis. ${ }^{170}$ Also, Leach's analyses of the use of such terms in the written sources would not substantiate her claims. Rather, George's chronological assumptions appear to be based on traditional labeling and on traditional beliefs that the perspectives of authors such as Vitruvius or Pliny explain the development of domestic behaviors in Campania because this behavior would have taken its lead from the elite in the capital. It is equally probable that domestic practices in Campania may have influenced those of the Roman elite, given its links with the Greek world. The evidence that George provides certainly does not rule out this possibility. Rather than demonstrating a change in ancient practice in this particular region, her analysis should motivate a change in modern perceptions of relationships between these houses and ancient written sources and a more rigorous approach to the potential regional and cultural specificity of the data.

One of the main problems for investigators of domestic practice, reliant on the excavations of others, is that the kind of contextualized data needed for the questions being asked is seldom available in a readily digestible form. For his investigation of the spatial arrangements of domestic activities in rural Roman Britain, Richard Hingley relied predominantly on the typologies of house plans and settlements, presumably because this was the main published evidence available to him that did not require the detailed and difficult task of examining unpublished excavation notes to attempt to reincorporate the finds into these spaces. ${ }^{171}$ Only the excavators of North Warnborough provided adequate information on artifact assemblages to distinguish any spatial separation of domestic activities, although not necessarily along the gender lines proposed by Hingley. ${ }^{172}$ Hingley's belief that Roman houses would have had separate gender areas again implies an analogy with

\footnotetext{
${ }^{169}$ George 1998, 88-93.

${ }^{170}$ George 1998, 95.

${ }^{171}$ Hingley 1989.

${ }^{172}$ Hingley 1989, 43-5.

${ }^{173}$ Esp. Allison 1992a.

${ }^{174}$ Foss 1994, 60.

${ }^{175}$ Foss 1994, esp. 58-62, 117.

${ }^{176}$ Allison 1992a, 296.
}

19th-century domestic practices.

Since my own study of artifact assemblages as Pompeian house contents, ${ }^{173}$ other artifact assemblage studies of these remains have also been carried out. In his study of kitchens and dining-rooms in Pompeii, Pedar Foss claimed to have used "architecture, art and decoration, graffiti and finds" as sources of evidence. ${ }^{174} \mathrm{He}$ rightly pointed out that contextual, typological, and statistical approaches to such material, though imprecise, can help to alleviate subjectivity. ${ }^{175}$ While he seemed to have taken such an approach to the structure and fixtures, he did not do so to the moveable finds, however. That is, he employed artifact assemblages to confirm spatial function as identified through structure and decoration rather than as independent evidence for the functions of particular spaces. A case in point is the assemblage in room $\mathrm{i}$ of House I $7,19,{ }^{176}$ which conceivably contained food preparation vessels but which is not included in Foss's analysis, ${ }^{177}$ as this room did not have the fixtures that would identify it as a cooking area. Equally, Foss's assumption, ${ }^{178}$ that the corollary of the presence of cooking apparatus indicating a functioning kitchen ${ }^{179}$ is that the lack of such finds indicates a non-functioning kitchen, shows a misunderstanding of the fragmentary and partial documentary nature of the material evidence. ${ }^{180}$ What is needed is an assessment of all the material evidence for cooking and food-preparation activities in Roman houses, which can then be analyzed for its relationship with the textual evidence. ${ }^{181}$

Joanne Berry listed finds from the Casa di M. Epidius Primus in Pompeii as reported in the excavation day-books. ${ }^{182}$ In a separate publication, she also investigated two other houses, Houses I 9,11 and I 9,12 , on an individual basis. ${ }^{183}$ Her approach was therefore similar to that of contributors to the Häuser in Pompeji series, where each house is treated in isolation, but Berry went further to investigate the contribution of these finds to our understanding of the occupancy and functioning of this house. Her interpretations of the patterning of the assemblages related to spatial and functional significance, however, are dependent on some inherent logic or a kind of "common sense view of facts based on

\footnotetext{
${ }^{177}$ Foss 1994, 275.

${ }^{178}$ Foss 1994, 60.

${ }^{179}$ Allison 1992a, 92-3.

${ }^{180}$ Cf. Nevett 1999, 63.

${ }^{181}$ For preliminary analyses in this regard, see Allison forthcoming, ch. 6.

${ }^{182}$ Berry 1997a.

${ }^{183}$ Berry $1997 \mathrm{~b}$.
} 
experience and biases." ${ }^{184}$ For example, her conclusions that "(a bronze jar and cauldron and a terracotta vase) could have been used for drawing water" or about the "'normal' artifacts in a triclinium" imply that the functions of Roman household artifacts and the furnishing of rooms in Roman houses are well understood. ${ }^{185}$ On the contrary, neither the furnishings of Roman spaces nor the functions of Roman artifacts has yet been rigorously researched. ${ }^{186}$ Berry's analyses are reminiscent of Olga Elia's 1930s study of the houses in Insula I, 10 at Pompeii. ${ }^{187}$ She used atheoretical, traditional approaches to Roman material culture, rather than exploring the much more active role that the material culture and its patterning can take in informing on domestic practice. ${ }^{188}$ With the availability of a wealth of closely related data for studies on artifact assemblages, recent interdisciplinary research into domestic material culture, and her own observation that her conclusions "need[s] to be tested against a much larger sample of housing," 189 one hopes that she will indeed use more rigorous and comprehensive approaches to the material record in the future.

Indeed, Berry had a similar dilemma to Hingley-the lack of readily available and reliable material data for comparative analyses from which to make more informed interpretations of the distribution patterns. The extraction of the data necessary to carry out such contextual study requires a considerable amount of time and dedication. George referred to such data from Pompeii, which is no longer in situ and therefore not visible to the site visitor, as "the missing evidence." 190 She also believed that the "furnishings of atria have not survived." As at any other archaeological site, the material and primary documentation resulting from the Pompeian excavations is held in archives, storerooms, or museums, and any scholar who wants to use the material remains and their documentation for a reinvestigation must consult this archive. While this archive might not constitute a complete documentation that can illustrate a "frozen moment" of the site, ${ }^{191}$ its contents are not "missing" from the scholarly world. On the contrary, a wealth

\footnotetext{
${ }^{184}$ Cf. Whitley 1998, 9.

${ }^{185}$ Berry 1997a, 193.

${ }^{186}$ See Allison 1992a, 1999a, forthcoming.

${ }^{187}$ Elia 1934.

${ }^{188}$ Cf. Miller 1987.

${ }^{189}$ Berry 1997a, 194.

${ }^{190}$ George 1998, 83.

${ }^{191}$ Allison 1992c
}

of evidence on the furnishings of so-called atria has survived in the Pompeii archives. ${ }^{192}$

There also is a belief, again articulated by George ${ }^{193}$ that to include a contextual study of all the material remains of Roman houses would only bring further complications to an already complicated area of study. This belief constitutes a misunderstanding of the nature of the material evidence and of archaeological practice. More than a quarter century ago Brigitta Tamm wrote of the need to abandon "old points of departure in the discussion about Roman houses ... [ [and] concentrate on other material instead." ${ }^{194}$ Nevertheless, scholars have continued to believe that architectural and ancient textual evidence inform on domestic behavior and that any lack of fit with artifactually-defined use of space is a symptom of the unreliability of the archaeological record. It would be more meaningful to take a critical approach to the relationships between ancient written references, with their various perspectives and agenda, and the totality of material record-the architecture, decoration, and contents. ${ }^{195}$ The investigation of the context and distribution of artifact assemblages across a large sample, with all its analytical complexities, can be used to show that room use identified by combining textual and architectural evidence is not always reliable. More importantly, such investigation can also isolate patterns of household behavior that might seem unexpected, given the often unconscious assumptions that are frequently made about universalities in domestic practice.

\section{Interdisciplinary Approaches}

Given the objectives of the investigators of Roman domestic space, some level of social theory is inherent in their approaches whether or not it is articulated by individual investigators. In more recent scholarship, there is an increasing trend to shift the focus of the study of Roman domestic space from the traditions of classical archaeology toward more engagement with current debates in the wider disciplines of archaeology and history concerning appropriate lines of inquiry and codes of practice. ${ }^{196}$ Following the leads taken by other branches

\footnotetext{
${ }^{192}$ See, e.g., Allison 1992a passim: 42-6; 1993; Berry 1997a, 188; 1997b, 109, 113-4.

${ }^{193}$ George $1997 \mathrm{~b}, 23$ n. 45.

${ }^{194}$ Tamm 1973, 55.

${ }^{195}$ My perspectives on this issue have been misrepresented by Laurence and by Berry. Compare Allison 1992a, 1993, 1995 with Laurence 1995, 1997, 10-11; Berry 1997a, 185, 193.

${ }^{196}$ See Storey 1999, esp. 203-7.
} 
of archaeological and historical research in the 1980s and 1990s, scholars investigating Roman domestic space have become increasingly concerned with developing more interdisciplinary approaches to their data.

Interdisciplinary borrowing is most apparent in the search for appropriate theoretical frameworks. It has become almost de rigeur for an investigator of Roman domestic space to include at least one theorist from philosophy or from some other area of the social sciences in his or her bibliography. One of the most popular, for both archaeological and anthropological studies of domestic space, is Pierre Bourdieu. ${ }^{197}$ The contribution of Bourdieu's study of the Kabyle house to studies of relationships between household material culture and domestic practice should not be undervalued. As Wallace-Hadrill has argued, ${ }^{198}$ however, this model is not necessarily appropriate for domestic practice and household interrelationships in the Roman world. Furthermore, Gabriele vom Bruck pointed out that, even in the Arab world, household relationships and spatial interrelationships are more complex and fluid than those presented by Bourdieu. ${ }^{199}$

Other social theorists whose work has influenced scholars of Roman domestic space include anthropologist Mary Douglas and economist Baron Isherwood. ${ }^{200}$ Sarah Scott stated that their "technology of consumption provides a useful starting point" for understanding the relationship between material and written evidence. ${ }^{201}$ The premise that consumption is ultimately about power links householders' ability to indulge in conspicuous consumption and to "overawe" their visitors by the opulence of their residences with their power status. ${ }^{202}$ Nevertheless, Scott warned of the danger of indiscriminate application of Douglas and Isherwood's approach. She acknowledged both that the relationship between the material and written sources is not self-explanatory but needs an articulated theoretical framework, and also that such frameworks are imbued with their own historical and cultural contingency. I believe that even more caution should be taken. For example, is it appropriate to assume, as Scott has, that the "low-ranking activities" in a late Roman villa are self-evident, and if so, to whom? ${ }^{203}$

\footnotetext{
${ }^{197}$ E.g., Carsten and Hugh-Jones 1995; Lawrence 1999.

${ }^{198}$ Wallace-Hadrill 1994, 8 n. 30.

${ }^{199}$ Vom Bruck 1997.

${ }^{200}$ Douglas and Isherwood 1979; see, e.g., Wallace-Hadrill 1994, 6.

${ }^{201}$ Scott 1997, 59.

${ }^{202}$ Scott 1997, 60.

${ }^{203}$ Scott 1997,60 .
}

To better understand the concepts of "public" and "private" in Roman houses, Mark Grahame followed a tradition in archaeology of spatial analysis, ${ }^{204}$ using Bill Hillier's and Julienne Hansen's social logic of space ${ }^{205}$ as the framework into which he has set ground plans from Pompeian houses. Through the process of “access analysis" (i.e., presenting the house as a series of open and closed cells linked by access routes), Grahame claimed to provide evidence on social behavior that is different from that acquired through the reading of ancient written sources. ${ }^{206}$ On the contrary, his results essentially demonstrated that central courtyards provided main access routes and a closed room "defends the privacy of the householder against outsiders." ${ }^{207}$ These results do not seem any more illuminating than or different from those acquired through incorporating the written and the material, specifically the ground plans. ${ }^{208}$ Laurence argued that Hillier and Hansen's approach can alter perceptions of space but is not a "theory of space." ${ }^{209}$ Studies such as Grahame's provide graphic representations of the arrangements of domestic space as an alternative to standard ground plans. They may help to clarify the articulation of that space for scholars familiar with this tradition of presentations of physical remains. ${ }^{210}$ Such presentations can in fact be more difficult to read than the original ground plan from which it is derived, with little evidence that they can change the readers' perceptions of that plan. ${ }^{211}$ They may be more accurate than readings consisting of a combination of standard ground plans and textual analogy, but at the same time they are often more restrictive. Essentially, Grahame's “access analysis” does not provide altered perceptions or improvement of the current state of our knowledge but rather another avenue for reading the material remains of the Roman world. Notably, the objective of Grahame's analysis was to use "access analysis" to alter our perception of "private" and "public" in the Roman domestic domain. This has, in fact, been more successfully achieved by critical approaches to the textual evidence. While Grahame acknowledged that the perception of the Roman houses as the "private sphere"

\footnotetext{
${ }^{204}$ Grahame 1997. See, e.g., papers in Samson 1990.

${ }^{205}$ Hillier and Hansen 1984.

${ }^{206}$ Grahame 1997, 164.

${ }^{207}$ Grahame 1997, 163.

${ }^{208}$ Grahame 1997, 163. Cf., e.g., Clarke 1991.

${ }^{209}$ Laurence 1997, 8.

${ }^{210}$ See papers in Clarke 1977.

${ }^{211}$ E.g., compare Grahame 1997, fig. 9a with fig. 9c.
} 
is naïve, Riggsby argued that we are still far from understanding ancient concepts of privacy. ${ }^{212}$ If, as Riggsby has emphasized, a lectus genialis indeed stood in the open tablinum, how were privacy and access related in the Roman world? How were access routes, which are visible in a ground plan, affected by closed and open doors, which usually are not depicted in ground plans? Studies such as Grahame's highlight that much more rigorous attention to these relationships and their specific cultural contexts is required.

For a "theory of space," Laurence turned to Henri Lefebvre. ${ }^{213}$ According to Laurence, ${ }^{214}$ Lefebvre's concept of "representations of space" is a valuable weapon against "processualists" attacks upon the use of literary evidence. Laurence highlighted Lefebvre's references to Vitruvius's incorporation of ideology and understanding "for the first formulation of . . . a unitary code" of space. ${ }^{215}$ Perhaps more relevant to the nature of the available evidence of Roman domestic behavior is Lefebvre's warning that "One might suppose on first consideration that architecture and texts relating to architecture [my emphasis] would be a better choice than literary texts proper. Unfortunately, any definition of architecture itself requires a prior analysis and exposition of the concept of space."216

I agree with Laurence that Vitruvius created an "ideal formula" that does not explain the workings of the spatial world in all antiquity. While its appropriateness for "understanding the relationship between what the archaeological record preserves of spatial practice and the representation of space" is valuable, ${ }^{217}$ its limitations and prescriptiveness, as discussed above and as emphasized by Lefebvre, mean that its application to the material remains risks equally limited and prescriptive interpretations of Roman domestic practice.

Laurence outlined the conceptual triad (spatial practice, representations of space, and representational space) that is fundamental to Lefebvre's "science of space," ${ }^{218}$ founded on Marx's trinity formula (land, capital, and labor). ${ }^{219}$ Laurence simplified this to a dichotomy between representation and practice, arguing that, in broad terms, the former corresponds to the literary sources and the latter to the material. This simplification makes no allowance for

\footnotetext{
${ }^{212}$ Riggsby 1999.

${ }^{213}$ Laurence 1997, 9-11; Lefebvre 1991.

${ }^{214}$ Laurence 1997, 10.

${ }^{215}$ Lefebvre 1991, 270-2.

${ }^{216}$ Lefebvre 1991, 15.

${ }^{217}$ Laurence 1997, 10.
}

differences between the producers and users of space or for the complexity of their interrelationships and their varying relationships to space. Rather, literary sources can provide evidence for spatial practice, representations of space, and representational space. Equally, much work has been carried out on representational aspects of material culture without direct redress to literary evidence for spatial ideologies. ${ }^{220}$ Indeed, Lefebvre recognized a "representational space" of the Etruscans that "became enshrined in architectural and urban practice."221 Laurence seems confused about assumptions of a master plan or traditional practice and how these can be investigated through material and literary sources. It is not a matter of either/or: each can inform on the ideological and practical use of space, and the differences between the types of information are as important as the similarities.

I am also perplexed that a Roman historian would use a philosopher's perceptions of the nature of space in the Roman world to set the framework for an investigation of that space. Do social theorists base their perceptions on the studies of the literary and material remains made by Roman historians and archaeologists? If so, in Lefebvre's case this would have been scholarship written before 1974. One hopes that the enormous amount of work that has been carried out on Roman space since then would have refined our own perspectives of this area of research. For example, I would take issue with Lefebvre's uses of Vitruvius's "precise description" as a premise for some universality of "the Roman house, [as] a response to clearly defined needs." ${ }^{222}$ The fact that the material remains nowhere fit Vitruvius's prescriptions precisely should rather indicate that such needs are far from "clearly defined." But if, in fact, sociologists and philosophers like Lefebvre have not found it necessary to engage with the work of contemporary Roman scholars for their understanding of the Roman world, and their readings of its remains, then there is something fundamentally wrong with our discipline.

An important issue in the study of Roman domestic space is the social concept of household, not as a socioeconomic unit but as a system of membership. The behaviors of the various members of that system are not readily readable in the material

\footnotetext{
${ }^{218}$ E.g., Lefebvre 1991, 33.

${ }^{219}$ See Lefebvre 1991, 325.

${ }^{220}$ E.g., Hodder 1982; papers in Parker Pearson and Richards 1994; Shanks and Hodder 1998.

${ }^{221}$ Lefebvre 1991, 41.

${ }^{222}$ Lefebvre 1991, 245.
} 
record. In a similar manner to textual and modern analogy, social theory has been used to bring social concepts of household behavior into interpretations of the material remains of household settings, but particularly into their structural remains. The application of analogy and of social theory to these remains can be used both to construct and to critique current concepts of houses and households in the Roman world. As with many of the examples outlined in previous sections of this paper, scholars looking for useful social theory have been reluctant to bring an understanding of the role of house contents into this comprehension of household behavior. Amos Rapoport argued for the lack of homogeneity between the producers and users of domestic space and for the significance of "nonfixed features" in informing on domestic practice. ${ }^{223}$ Similarly, Daniel Miller demonstrated the significance that objects acquire and how different groups can imbue household material culture with various roles and significance. ${ }^{224}$

As Glenn Storey has done, ${ }^{225}$ I reiterate Stephen Dyson's characterization of much of " $[\mathrm{t}]$ he research which results from the application of new approaches [as] often immature, trendy and superficial." ${ }^{226}$ Many such studies are the outcomes of doctoral theses, as the list of contributors to any TRAC volume will reveal, ${ }^{227}$ usually of limited candidature. Such scholars have been encouraged to apply innovative theoretical frameworks for viewing the Roman world. A major problem with this practice is the lack of time these scholars have to apply these frameworks to primary data from the Roman world, to test the appropriateness of the theory, and to evaluate the nature and extent of the data. As stated by Wallace-Hadrill "there is a temptation ... to bring new theoretical frameworks to bear without going back to a close scrutiny of the evidence." ${ }^{228}$ David Whitley has also pointed out that the controversial nature of much philosophical argument means that the authority of a particular theorist should not "stand alone" as evidence for the veracity of a particular interpretation resulting from that authority. ${ }^{229}$ The results of many such studies are that assumptions built on past interpretations of Roman domestic practice are often taken to be "facts." 230 These results do not necessarily throw new light on our understanding of the Roman world but rather dress it up in new clothing.

Such approaches are indeed a fundamental preliminary step in developing fresh perspectives on the investigation of Roman domestic space, but scholars turning to other disciplines for their theoretical frameworks must be fully aware of the roles of archaeological and historical research in the formulation of these theories. Richard Saller highlighted the importance of Greek and Roman traditions to the 19th-century intellectuals who laid the foundations for much of current philosophical and social theoretical thinking. ${ }^{231}$ For example, he argued that "a partial view" of Roman law was used by 19th-century lawyers to formulate legal terminology and the concepts of kinship. ${ }^{232}$ Then, anthropologists such as Lewis Morgan used this "partial view" in their approaches to comparing Western kinship systems with those of other societies. As Saller demonstrated, when Maurizio Bettini turned to anthropological studies of kinship to find a framework for his study of Roman kinship, the analogy had gone full circle. ${ }^{233}$ For this reason, Roman scholars need to have a thorough understanding of the production processes of the theoretical framework into which they are implanting their data.

\section{ASKING APPROPRIATE QUESTIONS OF DIVERSE DATA}

Moses Finley stated that it is false to speak of a relationship between history and archaeology but rather about two kinds of evidence about the past. ${ }^{234}$ It is not a question of priority or superiority of one type of evidence over the other. ${ }^{235}$ Studies of Roman domestic space undertaken by scholars, labeled either as social historians or archaeologists, ${ }^{236}$ need to follow lines of inquiry to which the particular evidence is best suited. Remarks such as "from archaeology alone we are unlikely to be able to divine any meaning of space" or "straight reading of archaeological evidence is next to impossible," 237 indicate a lack of understanding of the methodological and theoretical processes that the discipline of archaeology uses to read its evidence.

\footnotetext{
${ }^{223}$ Rapoport 1990; Allison 1999b.

${ }^{224}$ Miller 1987, 1994.

${ }^{225}$ Storey 1999, 206.

${ }^{226}$ Dyson 1989, 146.

${ }^{227}$ E.g., Meadows et al. 1997.

${ }^{228}$ Wallace-Hadrill 1997, 218.

${ }^{229}$ Whitley 1998, 12

${ }^{230}$ See Reece 1993, 37.
}

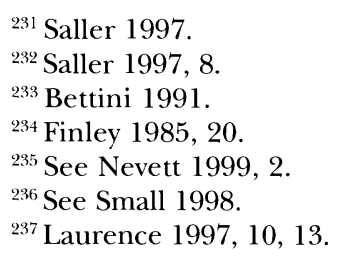


Reese produced an outline of the purposes of archaeological studies having little or no relevant written material. ${ }^{238} \mathrm{He}$ believed these purposes to be: to actually define the material, its spatial spread, and its chronological context; and to interpret the material evidence gathered. While such defining processes do not produce empirical facts, most archaeologists would agree that the first step is fundamental to their analysis in some form. ${ }^{239}$

Like the occupants of other Roman period sites, those of Pompeii have been referred to as "a people without a history." ${ }^{440}$ Pompeii is, therefore, not typical of a Roman site normally chosen for excavation in that it was not an important site in the historical record. Its importance is in its wealth of material culture, rather than its association with any known individuals and historical events. Because most ancient textual material is only broadly relevant to the Pompeian evidence, and to much of the material evidence uncovered at other sites, a more critical and rigorous approach to the remains should commence with Reece's first step. Given the amount of material remains at sites like Pompeii, and our own individual attention spans, our analytical approaches can have changed before this has been achieved so comprehensively that Reece's second step can be attempted within current theoretical frameworks. ${ }^{241}$ New and rigorous approaches to the same data can, however, continue to produce new information. Equally, analogy, whether textual or modern, can and should continue to be brought to bear on this data, but this analogy is not part of the original data.

As Laurence noted, our own changing worldviews allow us to reexamine "old evidence" in new light. ${ }^{242}$ Indeed the majority of the works discussed above do not involve any new evidence. While the importance of such reexamination seems self-evident in the study of ancient texts, archaeologists, ancient historians, and especially grant-funding bodies are often less generous in acknowledging its importance for investigations of material culture. Many recent scholars have embraced this need for reexamination by bringing new interdisciplinary approaches to this "old evidence" of Roman domestic

\footnotetext{
${ }^{238}$ Reece 1993, 30-1.

${ }^{239}$ See Whitley $1998,8-12$.

${ }^{240}$ Snodgrass 1991, 58.

${ }^{241}$ For similar reasons many of the catalogues of specific classes of Pompeian material culture (e.g., Scatozza Höricht 1986; Conticello De Spagnolis and De Carolis 1988) are notvery useful for investigations of Pompeian household behavior. See Allison 1999a; Leroi-Gourhan 1974, esp. 104.
}

space, and particularly to the Pompeian. The fundamental issue, however, is that previous interpretations of data, rather than the original data, are often analyzed. The dilemma is often that the data and information that should have been collected at Reece's first step are not readily available, particularly to scholars with more literary backgrounds. This is not the cry of a "processualist" 243 in the belief that "an objective reconstruction of the past can occur." 244 As Christopher Tilley stated, the "concern to be empirical, to consider the data in all its fullness and contextual associations, should not be confused with empiricism." ${ }^{245}$ It is very difficult to be rigorously interdisciplinary toward archaeological material without a good understanding of the methods and principles, and the "rigour and tedium," involved in the collection and analysis of that data and in archaeological practice generally. This does not mean that Roman historians have to wait for archaeologists to do the job properly. ${ }^{247}$ Rather they need to take into account the often already interpretative nature of the available information, and the significance of this to their own inquiries.

Without more rigorous approaches to the material remains, scholars, whether classified as historians or archaeologists, are reliant on secondary sources. As stated by Reece, "[i]f we take secondary sources then we are incorporating other people's theories into our theory as if they are material facts." 248 This is a constant dilemma for scholars trying to deal with the wealth of Roman material remains. Many projects involved in trying to improve the situation need to unpeel the layers of assumptions built into Roman studies. Synthetic studies, designed to fit the framework of a three-year degree program or a rushed conference paper, serve only to reiterate and thereby reinforce approaches and "factoids," which should rather be critically reappraised.

To use the material remains from Pompeii, or any other Roman period site, for investigations of domestic space, the complete material record should be carefully investigated to understand the formation processes before analogical inferences are brought to bear. For example, George's refer-

\footnotetext{
${ }^{242}$ Laurence 1997,7 .

${ }^{243}$ Laurence 1997, 10.

${ }^{244}$ Whitley $1998,7$.

${ }^{245}$ Tilley 1998, 321 .

${ }^{246}$ Flannery and Marcus 1998, 37, 46.

${ }^{247}$ See Whitelaw 1996.

${ }^{248}$ Reece 1993, 37.
} 
ence to the "original location" of statues in Campanian houses assumes that the material record in her chosen sample is deviant. ${ }^{249}$ The location of a statue in a certain house may not conform to a pattern found in other houses or to the parameters of social behavior prescribed by ancient written evidence. Rather, it may be an important indicator of the developmental cycle of this particular house. ${ }^{250}$ A more rigorous analysis of the distribution patterns of all sculpture in all Pompeian houses can provide more diachronic and more culturally and regionally sensitive perspectives of the varied and changing significance of sculpture in the Roman domestic sphere.

Once such material cultural approaches have been rigorously carried out, their relationships with analogical material, textual or cross-cultural, can be explored. At the same time it is not possible to rigorously analyze Roman material culture without some understanding of Roman society and society generally. I do not propose that written sources are not useful for investigations of domestic space. ${ }^{251}$ Rather I propose that the relationship between these sources, the lines of inquiry, and the analogies should be more rigorously and self-consciously investigated. Laurence has pointed out that there has recently been a growing awareness of the need for a more critical approach to the "use of vocabulary" in the study of domestic space. ${ }^{252}$ Scholars trained in the analysis of documentary sources, however, often turn to the material remains with questions derived through these textual analyses and are consequently frustrated with the inability of these remains to provide the answers they need, without recourse to textual analogy. A greater awareness of what Tilley terms "material metaphors" is needed. ${ }^{253}$

There is also a need for Roman historians to acknowledge that Roman archaeologists are not just data collectors and that their collections of data reflect patterns of social behavior that are not necessarily best understood by overlaying them with ancient textual references, often from unrelated contexts. The written sources are predominantly about household constitution and the physical layout of buildings. Archaeological investigations have traditionally been concerned with spatial layout, and hence with house construction, rather than occupancy-the producers rather than the consumers of

\footnotetext{
${ }^{249}$ George 1998, 85.

${ }^{250}$ Stenning 1969.

${ }^{251}$ Cf. Laurence 1997, 10.
}

Roman domestic space. Occupancy has often been studied atheoretically. Current questions regarding the behavior of people within this spatial layout require much more sensitive interaction between readings of the ancient texts, readings of the complete material record, social theory, and a critical appraisal of the biases inherited from past generations of Roman historians and archaeologists.

Approaches such as those of Leach and Riggsby point the way forward to more sensitive and critical readings of the written sources. ${ }^{254}$ They also provide a model for similarly critical readings of the material remains. But it is important that the latter also take their lead from the archaeological and material cultural investigations in other branches of the discipline. That is, investigators should first consult the original dataset and ask questions of that dataset itself. To posit a few elementary examples: how do excavated dwellings vary in ground plan, decorative detail, and range of room types; how does each room type vary in each context; how do the fixtures, artifacts, and other remains differ from room to room, or from house to house; is there any specific epigraphical or textual evidence that concerns this particular building (such Nero's Domus Aurea) or set of buildings; and what do these aspects tell us about the range of living conditions, and how do they vary between sites in the same region and in different regions; how would cross-disciplinary or feminist approaches interpret this material-cultural patterning and are these interpretations potentially relevant to these Roman period contexts?

Then detailed and critical analyses of the documentary sources and material remains can together form a baseline for integrating these varied sources of evidence. The patterns of social behavior produced by each must be rigorously explored to determine the significance of their similarities and differences. Do these result from an inaccurate reading of the material or the written remains or the use of inappropriate theoretical frameworks, or do they reflect differences that probably existed in the past and that can lead us to a better understanding of the social, geographical, and chronological ranges of domestic behavior in the Roman world? For example, what, if any, is the relationship between marble tables found in Pompeian houses and Varro's definition of a cartibulum,

\footnotetext{
${ }^{252}$ Laurence 1995, 313.

${ }^{253}$ Tilley 1999, esp. 262-73.

${ }^{254}$ See also Grahame 1999, 567.
} 
and how does this relationship inform on the chronological, social, and cultural relationships between domestic behavior in Pompeii and that of Varro's childhood?255

Above all, some questions can best be answered by one body of data and some by another, but many of the answers can be refined and reworked by constant renegotiations between the data, the theoretical frameworks, and their investigators.

\section{CONCLUSION}

Studies that combine ancient written evidence, predominantly from the Roman center, with architectural evidence from its peripheries to assess Roman household behavior run the risk of producing a prescriptive, architectural history rather than a truly social history. While it is important "to remove the stigma applied to history by some archaeologists," ${ }^{256}$ there is good reason to protest "the dominance of literary evidence in interpreting the function of domestic spaces in Pompeii." ${ }^{257}$ Latin labeling is indeed a useful, conventional classification system for the excavated spaces of Roman houses, ${ }^{258}$ particularly when research into Roman remains is carried out by scholars with a range of different mother tongues. Until this labeling can be validated by rigorous research, however, its use should be as a convention only. It should not be considered as the identification of household activities within physical remains and as a starting point for writing the social history of these extant physical remains.

In this paper I have exemplified a number of studies in which I feel the analytical procedures have not taken full account of the nature of the data and of the questions that they are capable of answering. There is, perhaps, an overrepresentation of examples from Laurence and Wallace-Hadrill; this is largely because their book claims to be concerned specifically with Roman domestic space. For many of the other works discussed here, the objective is not always so overtly to locate household behavior in its physical setting. These particular studies have been chosen for critique because they exemplify current approaches to Roman domestic space. As expressed by Tilley in an analogous context, "[t] hese are not personal criticisms, but criticisms of a tradition of

\footnotetext{
${ }^{255}$ See Allison 1999a, 61-2.

${ }^{256}$ Peebles 1998, 187.

${ }^{257}$ Leach 1997, 50.

${ }^{258}$ E.g., Peters et al. 1993, 403.

${ }^{259}$ Tilley 1999, 94.

${ }^{260}$ Cf. Laurence 1995, 313.
}

thought, an interrogation of a discourse rather than that of an individual who necessarily operates within its terms of reference." ${ }^{{ }_{259}}$ While this paper may give the negative impression that most current approaches to Roman domestic space are fundamentally flawed, that is not the intended message, nor is it the case within the field. Studies of Roman domestic space have advanced considerably in the last decade, qualitatively as well as quantitatively. Even the studies singled out here for critical appraisal show a theoretical sophistication not found in studies of the 1970s and 1980s. Nevertheless, current scholarship is generally still too positivist. ${ }^{260}$ There is a definite need among scholars working in this area to maintain a critical and self-reflexive approach to their interpretations. To continue to move forward, inherent biases, often based on our own ethnocentrisms, need to be first identified and then removed. ${ }^{261}$

In bringing together ancient historians and archaeologists in discussion over Roman domestic behavior, often in hot debate, much is owed to Wallace-Hadrill but not in the manner that has been assumed by Keith Bradley. Bradley's claim that "the influence of Andrew Wallace-Hadrill is evident throughout" ${ }^{262}$ what are ostensibly established archaeological approaches to Roman domestic space $^{263}$ is to credit him with having influenced the practice of archaeology as it has developed since the 1960s. Rather, scholars investigating domestic material culture of the Roman world are becoming more self-critical in their concern with marrying the methods of the New Archaeologists with the theories of the Post-processualists and with the questions of the social historians, so that their work is intelligible and indeed of interest to such historians. Andrew Wallace-Hadrill would not claim to have greatly influenced the discipline of archaeology, I hope. Rather, I believe that his work has had a major impact on the reception of archaeological investigations by Roman social historians. ${ }^{264}$

While this paper has concentrated on the study of Roman domestic space, I hope that many of the principles outlined in it apply to Roman historical and archaeological studies more generally, and to other branches of classical and historical archaeology. The study of domestic space is an ideal area for exploring relationships between the material evidence and

\footnotetext{
${ }^{261}$ See Whitelaw 1996, 319; Whitley 1998, 11.

${ }^{262}$ Bradley 1998, 133.

${ }^{263}$ I.e., George 1997a; Nevett 1997; Allison 1997b.

${ }^{264} \mathrm{His}$ own awareness of more archaeological approaches has had a significant impact on his students (e.g., Berry 1997a, 1997b).
} 
other sources, mainly because it is well represented in the material evidence and contrastingly poorly represented in the written sources, and certainly, until recently, in investigations of the latter.

Despite an increase in recent interdisciplinary approaches to domestic space within the context of Roman studies, the latter have seldom contributed to studies of domestic space across the wider discipline of archaeology. ${ }^{265}$ Interestingly, Roman case studies were not included in Susan Kent's book on domestic space ${ }^{266}$ and the Roman contribution to Colin Richard's and Michael Parker Pearson's volume is by a lecturer in architecture, interested in design theory. ${ }^{267}$ Similarly, there is little interaction between Roman scholars interested in domestic space and scholars in other disciplines, such as architecture, anthropology, and cultural studies, who are concerned with similar principles. Given the enormous impact of Roman domestic architecture and potentially of Roman household behavior on modern Western culture, Andrew Sherratt's lament at the lack of interaction between historians and archaeologists $^{268}$ can be extended to the lack of contribution that Roman scholars are making to the wider world of the humanities and social sciences.

A study of Roman domestic space that is acutely aware of its biases, overinterpretations, and ethnocentrisms and that has taken steps to eradicate them can make a substantial contribution to our understandings about relationships between written and material evidence and between our own domestic worlds and those of the past. It can thus make a real contribution to modern perceptions of the longevity and durability of different types or sets of social relationships.

\section{DEPARTMENT OF ARCHAEOLOGY}

UNIVERSITY OF SYDNEY

SYDNEY N.S. W 2006

AUSTRALIA

PIM.ALLISON@ARCHAEOLOGY.USYD.EDU.AU

\section{Works Cited}

Allison, P.M. 1991. "A Computer Database of Pompeian House Contents and its Application.” AJA 95:305.

— 1992a. "The Distribution of Pompeian House Contents and its Significance." Ph.D. diss., University of Sydney.

. 1992b. "The Relationship between Wall-Decoration and Room-Type in Pompeian Houses: A Case

\footnotetext{
${ }^{265}$ See Whitelaw 1996, 319-20.

${ }^{266}$ Kent 1990.
}

Study of the Casa della Caccia Antica." JRS 5:235-49. . 1992c. "Artifact Assemblages: Not the Pompeii Premise." In Papers of the Fourth Conference of Italian Archaeology, London 1990. Vol. 3, pt. 1, edited by E. Herring, R. Whitehouse, and J. Wilkins, 49-56. London: Accordia Research Centre.

. 1993. "How do We Identify the Use of Space in Roman Housing?" In Functional and Spatial Analysis of Wall Painting: Proceedings of the Fifth International Congress on Ancient Wall Painting, edited by E. Moormann, 1-8. BABesch Suppl. 3. Leiden: BABesch.

- 1994. "Room Use in Pompeian Houses." In Pompeii Revisited: The Life and Death of a Roman Town, J.-P. Descœudres et al., 82-9. Sydney: Meditarch.

. 1995. "House Contents in Pompeii: Data Collection and Interpretative Procedures for a Reappraisal of Roman Domestic Life and Site Formation Processes.” Journal of European Archaeology 3:145-76.

- 1997a. "Why do Excavation Reports Have Finds Catalogues?" In Not so Much a Pot, More a Way of Life, edited by C.G. Cumberpatch and P.W. Blinkhorn, 7784. Oxford: Oxbow.

1997b. "Artefact Distribution and Spatial Function in Pompeian Houses." In The Roman Family in Italy: Status, Sentiment and Space, edited by B. Rawson and P. Weaver, 321-54. Oxford: Clarendon.

. 1997c. "Subject Matter and Meaning in the Paintings of the Casa della Caccia Antica in Pompeii." In $I$ temi figurativi nella pittura parietale antica, Atti del VI Convegno Internazionale, edited by D. Scagliarini Corlàita, 19-24. Bologna: University of Bologna Press.

1998. "Pompeian Epigraphy as Archaeological Evidence." In Festschrift for Beryl Rawson, presentation volume in honour of Professor Beryl Rawson's retirement. N.p.

1999a. "Labels for Ladles: Interpreting the Material Culture of Pompeian Households." In The Archaeology of Household Activities, edited by P.M. Allison, 57-77. London: Routledge.

. 1999b. "Introduction." In The Archaeology of Household Activities, edited by P.M. Allison, 1-18. London: Routledge.

. Forthcoming. Pompeian Households: An Analysis of the Material Culture. Los Angeles: Cotsen Institute of Archaeology, UCLA.

Alston, R. 1997. "Houses and Households in Roman Egypt.” In Domestic Space in the Roman World: Pompeii and Beyond, edited by R. Laurence and A. WallaceHadrill, 25-39. JRA Suppl. 22. Portsmouth: Journal of Roman Archaeology.

Anderson, J.C., jr. 1997. Architecture and Society. Baltimore and London: Johns Hopkins University Press.

Andreae, M.T. 1990. "Tiermegalographien in pompeianischen Gärten.” Rivista di Studi Pompeiani 4:45-124.

Ault, B. 1994. "Classical Houses and Households: An Architectural and Artifactual Case Study from Haleis, Greece." Ph.D. diss., Indiana University.

Barbet, A. 1985. La peinture murale romaine. Paris: Picard.

Barrett, J.C. 1997. "Romanization: A Critical Comment."

\footnotetext{
${ }^{267}$ Knights 1994.

${ }^{268}$ Sherratt 1992, 140
} 
In Dialogues in Roman Imperialism, edited by D. Mattingly, 51-64. JRA Suppl. 23. Portsmouth: Journal of Roman Archaeology.

Becker, W.A. 1876. Gallus. 5th ed. London: Longmans, Green and Co.

Berry, J. 1997a. "Household Artifacts: Towards a ReInterpretation of Roman Domestic Space." In Domestic Space in the Roman World: Pompeii and Beyond, edited by R. Laurence and A.F. Wallace-Hadrill, 183-96. JRA Suppl. 22. Portsmouth: Journal of Roman Archaeology.

- 1997b. "The Conditions of Domestic Life in Pompeii in AD 79: A Case-Study of Houses 11 and 12, Insula 9, Region 1.” BSR 65:103-25.

Bettini, M. 1991. Anthropology and Roman Culture: Kinship, Time, Images of the Soul. Baltimore: Johns Hopkins University Press.

Boak, A.E.R., and E.E. Petersen. 1931. Karanis 1924-28. University of Michigan Studies, Humanities series 25. Ann Arbor: University of Michigan Press.

Bon, S., and R. Jones. 1997. "Sequence and Space in Pompeii: An Introduction." In Sequence and Space in Pompeii, edited by S.E. Bon and R. Jones. Oxbow Monograph 77. Oxford: Oxbow.

Bradley, K. 1991. Discovering the Roman Family: Studies in Roman Social History. Oxford: Oxford University Press. . 1998. "The Roman Family: New Directions." Vues du Monde Classique/Classical Views 17:129-37.

Bruno, V., and R.T. Scott. 1993. Cosa. Vol. 6, The Houses. Memoirs of the American Academy in Rome 38. Rome: American Academy in Rome.

Carandini, A. 1990. "'Domus' artistocratica sopra le mura e il pomerio del Palatino." In La Grande Roma dei Tarquini, edited by M. Cristofani (Exhibition catalogue) 97-9. Rome: "L'ERMA" di Bretschneider.

Carsten, J., and S. Hugh-Jones. 1995. About the House: Lévi-Strauss and beyond. Cambridge: Cambridge University Press.

Clarke, D.L., ed. 1977. Spatial Archaeology. London: Academic.

Clarke, J.R. 1991. The Houses of Roman Italy, 100 B.C.A.D. 250: Ritual, Space and Decoration. Berkely, Los Angeles and Oxford: University of California Press.

Conticello De Spagnolis, M., and E. De Carolis. 1988. Le lucerne di bronzo di Ercolano e Pompei. Rome: "L'ERMA" di Bretschneider.

Corlàita Scagliarini, D. 1974-1976. "Spazio e decorazione nella pittura pompeiana." Palladio 24-26:3-44.

Daviau, M. 1993. Houses and their Furnishings in Bronze Age Palestine: Domestic Activity Areas and Artefact Distribution in the Middle and Late Bronze Ages. Journal for the Study of the Old Testament Suppl. 143. Sheffield: Sheffield Academic Press.

De Haan, N. 1993. "Dekoration und Funktion in den Privatbäden von Pompeji und Herculaneum." In Functional and Spatial Analysis of Wall Painting: Proceedings of the Fifth International Congress on Ancient Wall Painting, edited by E. Moormann, 34-7. BaBesch Suppl. 3. Leiden: BABesch.

De Vos, A., and M. De Vos. 1982. Pompei, Ercolano, Stabia. Rome and Bari: Guide archeologiche Laterza.

Della Corte, M. 1965. Case ed Abitanti di Pompei. 3rd ed. Naples: Fausto Fiorentino.

Descoeudres, J.-P., et al. 1994. Pompeii Revisited: The Life and Death of a Roman Town. Sydney: MeditArch.
Dexter, C.E. 1974. "The Casa di Cecilio Giocondo in Pompeii." Ph.D. diss., Duke University.

Dickmann, J.-A. 1997. "The Peristyle and the Transformations of Domestic Space in Hellenistic Pompeii." In Domestic Space in the Roman World: Pompeii and Beyond, edited by R. Laurence and A. Wallace-Hadrill, 121-36. JRA Suppl. 22. Portsmouth: Journal of Roman Archaeology.

Dixon, S. 1992. The Roman Family. Baltimore: Johns Hopkins University Press.

Douglas, M., and B. Isherwood. 1979. The World of Goods: Towards an Anthropology of Consumption. London: Allen Lane.

Drummer, A. 1994. "Villa: Untersuchungen zum Bedeutungswandel eines Motivs in römischer Bildkunst und Literatur." Ph.D. diss., Ludwig-Maximilians-Universität, Munich.

Dunbabin, K.M.D. 1995. "Houses and Households of Pompeii." JRA 8:387-90.

- 1996. "Convivial Spaces: Dining and Entertainment in the Roman Villa." JRA 9:66-80.

Dwyer, E.J. 1982. Pompeian Domestic Sculpture: A Study of Five Pompeian Houses. Rome: Giorgio Bretschneider.

Dyson, S.L. 1989. "The Relevance for Romanists of Recent Approaches to Archaeology in Greece." JRA 2:143-6.

1993. "From New to New Age Archaeology: Archaeological Theory and Classical Archaeology-A 1990s Perspective." AJA 97:195-206.

1995. "Is there a Text in this Site?" In Methods in the Mediterranean: Historical and Archaeological Views on Texts and Archaeology, edited by D.B. Small, 25-44. London: Brill.

Ehrhardt, W. 1998. Casa di Paquius Proculus, Häuser in Pompeji 9. Munich: Hirmer.

Elia, O. 1934. "Relazione sullo scavo dell'Insula X della Regio I." NSc:264-344.

Eristov, H. 1993. "Atrium, tablinum, ala: enquête sur quelques décors pompéiens disparus." In Functional and Spatial Analysis of Wall Painting: Proceedings of the Fifth International Congress on Ancient Wall Painting, edited by E. Moormann, 187-93. BaBesch Suppl. 3. Leiden: BABesch.

Finley, M.I. 1985. Ancient History: Evidence and Models. London: Chatto \& Windus.

Flannery, K.V., and J. Marcus. 1998. "Cognitive Archaeology." In Reader in Archaeological Theory: Post-Processual and Cognitive Approaches, edited by $\mathrm{D}$. Whitley, 3548. London: Routledge.

Förtsch, R. 1993. Archäologischer Kommentar zu den Villenbriefen des jüngeren Plinius. Mainz: Philipp von Zabern.

Foss, P. 1994. "Kitchens and Dining Rooms at Pompeii: The Spatial and Social Relationship of Cooking to Eating in the Roman Household.” Ph.D. diss., University of Michigan.

- 1997. "Watchful Lares: Roman Household Organization and the Rituals of Cooking and Dining." In Domestic Space in the Roman World: Pompeii and Beyond, edited by R. Laurence and A.F. Wallace-Hadrill, 196-218. JRA Suppl. 22. Portsmouth: Journal of Roman Archaeology.

Fröhlich, T. 1993. "Die Wanddekorationen des Peristyls der Casa della Fontana Piccola in Pompeji." In Functional and Spatial Analysis of Wall Painting: Proceedings of the Fifth International Congress on Ancient Wall Paint- 
ing, edited by E. Moormann, 72-81. BaBesch Suppl. 3. Leiden: BABesch.

Fulford, M., and A.F. Wallace-Hadrill. 1998. "Unpeeling Pompeii." Antiquity 72:128-45.

Gallivan, P., and P. Wilkins. 1997. "Familial Structures in Roman Italy: A Regional Approach.” In The Roman Family in Italy: Status, Sentiment and Space, edited by B. Rawson and P. Weaver, 239-79. Oxford: Oxford University Press.

Gardner, J., and T. Wiedemann. 1991. The Roman Household: A Sourcebook. London and New York: Routledge.

Gassner, V. 1986. "Die Kaufläden in Pompeii." Ph.D. diss., Vienna University. Wien: VWGÖ.

Gazda, E., ed. 1991. Roman Art in the Private Sphere: New Perspectives of the Architecture and Décor of the Domus, Villa, and Insula. Ann Arbor: University of Michigan Press.

George, M. 1997a. "Repopulating the Roman House." In The Roman Family in Italy: Status, Sentiment and Space, edited by B. Rawson and P. Weaver, 297-319. Oxford: Clarendon.

C. 1997b. "Servus and Domus: The Slave in the Roman House." In Domestic Space in the Roman World: Pompeii and Beyond, edited by R. Laurence and A.F. Wallace-Hadrill, 15-24. JRA Suppl. 22. Portsmouth: Journal of Roman Archaeology.

1998. "Elements of the Peristyle in Campanian Atria." JRA 11:82-100.

Grahame, M. 1997. "Public and Private in the Roman House: Investigating the Social Order of the Casa del Fauno." In Domestic Space in the Roman World: Pompeii and Beyond, edited by R. Laurence and A.F. WallaceHadrill, 137-64. JRA Suppl. 22. Portsmouth: Journal of Roman Archaeology.

- 1998. "Material Culture and Roman Identity." Cultural Identity in the Roman Empire, edited by R. Laurence and J. Berry, 156-78. London: Routledge. 1999. "Recent Developments in Pompeian Archaeology." JRA 12:567-75

Hillier, B., and J. Hansen. 1984. The Social Logic of Space. Cambridge: Cambridge University Press.

Hingley, R. 1989. Rural Settlement in Roman Britain. London: Seaby.

. 1998. "The Imperial Context of Romano-British Studies and Proposals for a New Understanding of Social Change." In Historical Archaeology: Back from the Edge, edited by P.P.A. Funari, M. Hall, and S. Jones, 137-50. One World Archaeology 31. London and New York: Routledge.

Hodder, I., ed. 1982. Symbolic and Structural Archaeology. Cambridge: Cambridge University Press.

Hope, V. 1997. "A Roof over the Dead: Communal Tombs and Family Structure." In Domestic Space in the Roman World: Pompeii and Beyond, edited by R. Laurence and A.F. Wallace-Hadrill, 69-88. JRA Suppl. 22. Portsmouth: Journal of Roman Archaeology.

Husselman, E.M. 1979. Karanis Excavations of the University of Michigan in Egypt, 1928-1935: Topography and Architecture. University of Michigan Kelsey Museum of Archaeology Studies 5. Ann Arbor: University of Michigan Press.

Jansen, G.C.M. 1993. "Paintings in Roman Toilets.” In Functional and Spatial Analysis of Wall Painting: Proceedings of the Fifth International Congress on Ancient Wall Painting, edited by E. Moormann, 29-33. BaBesch Sup- pl. 3. Leiden: BABesch.

Johnson, M. 1990. "The Englishman's Home and its Study." In The Social Archaeology of Houses, edited by R. Samson, 245-57. Edinburgh: Edinburgh University Press.

Karskens, G. 1997. The Rocks: Life in Early Sydney. Melbourne: Melbourne University Press.

Kent, S., ed. 1990. Domestic Architecture and the Use of Space: An Interdisciplinary Cross-Cultural Study. Cambridge: Cambridge University Press.

Kleiwegt, M. 1999, 20 March. Review of Roman Villas: A Study of Social Structure, by J.T. Smith. BMCR 10 (1999). http://ccat.sas.upenn.edu/bcmr/1999/1999-320.html.

Knights, C. 1994. "The Spatiality of the Roman Domestic Setting: An Interpretation of Symbolic Content." In Architecture and Order, edited by M. Parker Pearson and C. Richards, 113-46. London: Routledge.

Krauss, S. 1966. Reprint. Talmudische Archäologie. 3 vols. Hildesheim: Georg Olms.

Laurence, R. 1995. Review of Functional and Spatial Analysis of Wall Painting: Proceedings of the Fifth International Congress on Ancient Wall Painting, edited by E. Moormann; Enchanted Landscapes: Wall Paintings from the Roman Era, by S. Rozenberg; Les Elements Architecturaux dan la Peinture Campaniene du Quatrième Style, by H. Eristov. JRS 85:313-4.

- 1997. "Space and Text." In Domestic Space in the Roman World: Pompeii and Beyond, edited by R. Laurence and A.F. Wallace-Hadrill, 7-14. JRA Suppl. 22. Portsmouth: Journal of Roman Archaeology.

Laurence, R., and A.F. Wallace-Hadrill, eds. 1997. Domestic Space in the Roman World: Pompeii and Beyond. JRA Suppl. 22. Portsmouth: Journal of Roman Archaeology.

Lawrence, S. 1999. "Towards a Feminist Archaeology of Households: Gender and Household Structure on the Australian Goldfields." In The Archaeology of Household Activities, edited by P.M. Allison, 121-41. London and New York: Routledge.

Leach, E.W. 1997. "Oecus on Ibycus: Investigating the Vocabulary of the Roman House." In Sequence and Space in Pompeii, edited by S.E. Bon and R. Jones, 5072. Oxbow Monograph 77. Oxford: Oxbow.

Lefebvre, H. 1991. The Production of Space. Translated by D. Nicholson-Smith. Oxford: Blackwell.

Leroi-Gourhan, A. 1974. "Les voies de l'histoire avant l'écriture." In Faire de L'histoire I: Nouvelle Problèmes, edited by J. le Goff and P. Nora, 93-105. Paris: Gallimard.

Ling, R. 1997. The Insula of the Menander at Pompeii. Vol. 1, The Structures. Oxford: Oxford University Press.

Maiuri, A. 1933. La Casa del Menandro e il suo Tesoro di Argenteria. Roma: Libreria dello Stato.

Mar, R. 1995. "Las casa de atrio en Pompeya: Cuestiones di tipología." ArchCl47:103-37.

Mattingly, D.J., ed. 1997. Dialogues in Roman Imperialism. JRA Suppl. 23. Portsmouth: Journal of Roman Archaeology.

Mau, A. 1899. Pompeii: Its Life and Art. Translated by F.W. Kelsey. London: MacMillan and Co.

Meadows, K. 1999. "The Appetites of Households in Early Roman Britain." In The Archaeology of Household Activities, edited by P.M. Allison, 101-20. London: Routledge. 
Meadows, K., C. Lemke, and J. Heron, eds. 1997. TRAC 96: Proceedings of the Sixth Annual Theoretical Roman Archaeology Conference. Oxford: Oxbow.

Meyer, K.E. 1999. "Axial Peristyle Houses in the Western Empire." JRS 12:101-21.

Michel, D. 1980. "Pompejanische Gartenmalerei." In Tainia, Festschrift für Roland Hampe, edited by H. Cahn and E. Simon, 373-404. Mainz: Philipp von Zabern.

Miller, D. 1987. Material Culture and Mass Consumption. Oxford and New York: Blackwell.

Moormann, E., ed. 1993. Functional and Spatial Analysis of Wall Painting: Proceedings of the Fifth International Congress on Ancient Wall Painting. BaBesch Suppl. 3. Leiden: BABesch.

Morris, I.M., ed., 1994. Classical Greece: Ancient Histories and Modern Archaeologies. Cambridge: Cambridge University Press.

Mouritsen, H. 1988. Elections, Magistrates and Municipal Elite. Rome: "L'ERMA" di Bretschneider.

Muecke, F. 1996. "Horace's Rome." Classicum 21 (2):29-34.

Neudecker, R. 1988. Die Skulpturen-Ausstattung römischer Villen in Italien. Mainz: Philipp von Zabern.

Nevett, L. 1997. "Perceptions of Domestic Space." In The Roman Family in Italy: Status, Sentiment and Space, edited by B. Rawson and P. Weaver, 281-98. Oxford: Clarendon.

1999. House and Society in the Ancient Greek World. Cambridge: Cambridge University Press.

Overbeck, J. 1856. Pompeji in seinen Gebäude, Alterthümern und Kunstwerken für Kunst- und Alterthumsfreunde. Leipzig: Wilhelm Englemann.

Parker Pearson, M., and C. Richards, eds. 1994. Architecture and Order. London: Routledge.

Parslow, C.C. 1995. Rediscovering Antiquity: Karl Weber and the Excavation of Herculaneum, Pompeii and Stabiae. Cambridge: Cambridge University Press.

Peebles, C.S. 1998. "Annalistes, Hermeneutic and Positivists: Squaring the Circles of Dissolving Problems." In Reader in Archaeological Theory: Post-Processual and Cognitive Approaches, edited by D. Whitley, 183-97. London: Routledge.

Pesando, F. 1997. Domus: Edilizia privata e società pompeiana fra III e I secolo a.C. Rome: "L'ERMA" di Bretschneider.

Peters, W.J. Th. et al. 1993. La Casa di Marcus Lucretius Fronto a Pompei e le sue pitture. Amsterdam: Thesis.

Pirson, F. 1997. "Rented Accommodation at Pompeii: The Evidence of the Insula Arriana Polliana VI 6." In Domestic Space in the Roman World: Pompeii and Beyond, edited by R Laurence and A. Wallace-Hadrill, 16581. JRA Suppl. 22. Portsmouth: Journal of Roman Archaeology.

Purcell, N. 1994. The City of Rome and the Plebs Urbana in the Late Republic, CAHIX (2nd ed.), 644-88. Cambridge: Cambridge University Press.

Rapoport, A. 1990. The Meaning of the Built Environment: A Non-Verbal Communication Approach. Tucson: University of Arizona Press.

Rawson, B. 1997a. "Representations of Roman Children and Childhood." Antichton 31:74-95.

1997b. "The Iconography of Roman Childhood." In The Roman Family in Italy: Status, Sentiment and Space, edited by B. Rawson and P. Weaver, 205-32. Oxford: Oxford University Press.

Rawson, B., and P. Weaver, eds, 1997. The Roman Family in Italy: Status, Sentiment and Space. Oxford: Oxford University Press.

Reece, R. 1993. "Theory and Roman Archaeology.” In Theoretical Roman Archaeology: First Conference Proceed ings, edited by E. Scott, 29-38. Aldershot: Avebury.

Richardson, L., jr. 1955. The Casa dei Dioscuri and its Painters. MAAR 23. Rome: American Academy in Rome.

1988. Pompeii: An Architectural History. Baltimore and London: Johns Hopkins University Press.

Riggsby, A.M. 1997. "'Private' and 'Public' in Roman Culture: The Case of the Cubiculum." JRA 10:36-56. . 1999. "Integrating Public and Private." JRA $12: 555-8$.

Roaf, M. 1989. "Ubaid Social Organization and Social Activities as Seen from Tell Madhhur." In Upon this Foundation: The Ubaid Reconsidered, edited by E.F. Henrickson and I. Thuesen, 91-146. Copenhagen: Museum Tusculanum Press.

Sackett, L.H. 1992. Knossos: From Greek City to Roman Col ony: Excavations at the Unexplored Mansion II. British School of Archaeology at Athens Suppl. 21. Athens: The British School of Archaeology at Athens.

Saller, R. 1997. "Roman Kinship: Structure and Sentiment." In The Roman Family in Italy: Status, Sentiment and Space, edited by B. Rawson and P. Weaver, 7-34. Oxford: Clarendon.

Samson, R., ed. 1990. The Social Archaeology of Houses. Edinburgh: Edinburgh University Press.

Scatozza Höricht, L.A. 1986. I vetri romani di Ercolano. Rome: "L'ERMA" di Bretschneider.

Schiffer, M.B. 1996. Formation Processes of the Archaeological Record. Salt Lake City: University of Utah Press.

Scott, E. 1990. "Romano-British Villas and the Social Construction of Space." In The Social Archaeology of Houses, edited by R. Samson, 149-72. Edinburgh: Edinburgh University Press.

Scott, S. 1997. "The Power of Images in the Late Roman House." In Domestic Space in the Roman World: Pompeii and Beyond, edited by R. Laurence and A. WallaceHadrill, 53-67. JRA Suppl. 22. Portsmouth: Journal of Roman Archaeology.

Seiler, F. 1992. Casa degli Amorini Dorati, Häuser in Pompeji, vol. 5. Munich: Hirmer.

Sherratt, A. 1992. "What Can Archaeologists Learn from Annalistes?” In Archaeology, Annales and Ethnohistory, edited by A.B. Knapp, 135-42. Cambridge: Cambridge University Press.

Shanks, M. 1999. Art and the Greek City State: An Interpretative Archaeology. Cambridge: Cambridge University Press.

Shanks, M., and I. Hodder. 1998. "Interpretative Archaeologies." In Reader in Archaeological Theory: Post-Processual and Cognitive Approaches, edited by D. Whitley, 69-95. London: Routledge.

Sichtermann, H. 1974. "Gemalte Garten in pompejanischen Zimmern." AntW5 (3):41-51.

Small, D.B. 1998. "The Tyranny of the Text: Lost Social Strategies in Current Historical Period Archaeology in the Classical Mediterranean.” In Historical Archaeology: Back from the Edge, edited by P.P.A. Funari, M. Hall, and S. Jones, 122-36. One World Archaeology 31. London: Routledge.

Smith,J.T. 1997. Roman Villas: A Study of Social Structure. London: Routledge

Snodgrass, A. 1991. "Structural History and Classical 
Archaeology." In The Annales School and Archaeology, edited by J. Bintliff, 57-72. Leicester: University of Leicester Press.

Stenning, D.J. 1969. "Household Viability among Pastoral Fulani." In Developmental Cycles in Domestic Groups, edited by J. Goody, 92-112. Cambridge: Cambridge University Press.

$\rightarrow$ Storey, G. 1999. "Archaeology and Roman Society: Integrating Textual and Archaeological Data." Journal of Archaeological Research 7 (3):203-48.

Strocka, V.M. 1975. "Pompejanische Nebenzimmer." In Neue Forschungen in Pompeji, edited by B. Andreae and H. Kyrieleis, 101-14. Recklinghausen: Bongers.

. 1984. Casa del Principe di Napoli, Häuser in Pompeji, vol. 1. Tübingen: Wasmuth.

1993. "Pompeji VI 17, 41: Ein Haus mit Privatbibliothek." RM100:321-51.

Tamm, B. 1973. "Some Notes on Roman Houses." OpRom 9 (6):53-60.

Thébert, Y. 1987. "Private Life and Domestic Architecture in Roman North Africa." In A History of Private Life: From Pagan Rome to Byzantium, edited by P. Veyne, 313-409. Translated by A. Goldhammer. Cambridge: Harvard University Press.

Tilley, C. 1998. "Archaeology as Socio-Political Action in the Present." In Reader in Archaeological Theory: PostProcessual and Cognitive Approaches, edited by D. Whitley, 305-30. London: Routledge.

Blackwell

Tybout, R.A. 1993. "Malerei und Raumfunktion im zweiten Stil." In Functional and Spatial Analysis of Wall Painting: Proceedings of the Fifth International Congress on Ancient Wall Painting, edited by E. Moormann, 38-50. BaBesch Suppl. 3. Leiden: BABesch.

Vom Bruck, G. 1997. "A House Turned Inside Out: Inhabiting Space in a Yemini City." Journal of Material Culture 2:139-72.

Wallace-Hadrill, A.F. 1994. Houses and Society in Pompeii and Herculaneum. Princeton: Princeton University Press. 1997. "Rethinking the Roman Atrium House." In Domestic Space in the Roman World: Pompeii and Beyond, edited by R. Laurence and A.F. Wallace-Hadrill, 219-40. JRA Suppl. 22. Portsmouth: Journal of Roman Archaeology.

Whitelaw, T. 1996. Review of Houses and Society in Pompeii and Herculaneum by A.F. Wallace-Hadrill, CAJ 6 (2): 317-20.

Whitley, D. 1998. "New Approaches to Old Problems." In Reader in Archaeological Theory: Post-Processual and Cognitive Approaches, edited by D. Whitley, 1-28. London: Routledge.

Wiseman, T.P. 1998. Roman Drama and Roman History. Exeter: University of Exeter Press.

Woolf, G. 1998. Becoming Roman: The Origins of Provincial Civilization in Gaul. Cambridge: Cambridge University Press.

$\rightarrow$ Wylie, A. 1985. "The Reaction against Analogy." Advances in Archaeological Method and Theory 8:63-111.

Zanker, P. 1998. Pompeii: Public and Private Life. Translated by D.L. Schneider. Cambridge: Harvard University Press. 